\title{
Decadal changes of the early summer Asian monsoon and the South China Sea tropical cyclones during 2001-2020
}

Yin-Min Cho ${ }^{1}$, Mong-Ming Lu ${ }^{1 *}$ (D), Chung-Hsiung Sui ${ }^{1}$, Ana L. S. Solis ${ }^{2}$ and Meng-Shih Chen ${ }^{3}$

\begin{abstract}
An inter-decadal increase (1990-2009) in the western North Pacific (WNP) tropical cyclone (TC) genesis frequency in May has recently been reported. The TC decadal changes was attributed to an advanced monsoon onset over the Asian Summer Monsoon region, particularly over the South China Sea (SCS) in May. In the present study, we used 60 years (1961-2020) of TC data and 40 years (1981-2020) of the global reanalysis data to investigate the unique changes of the SCS TC activity during May and the associated large-scale environment. We find that the increasing trend was weakened during the most recent decade (2011-2020), and the advanced monsoon onset was not discernable. The period of 2011-2020 was identified as a decade of the minimum TC genesis frequency over the SCS in May since 1961. The extremely inactive TC genesis was attributed to the weak low-level cross equatorial monsoonal flow over the Indo-Pacific warm pool and the weak westerly monsoon (easterly anomalies) north of equator from the western Pacific through the Philippine Sea and the SCS to the Bay of Bengal. The weak tropical monsoon was associated with subtropical anticyclonic and suppressed convection north of the equator and the opposite wind and convection south of the equator. The anticyclonic circulation over the SCS was particularly strong that inhibited TC genesis during the first decade of the twenty-first century.
\end{abstract}

\section{Key points}

- The SCS saw an unprecedentedly quiet decade with no TC genesis in May from 2010-2019.

- The decadal SCS low-level circulation anomaly in May was more anticyclonic after 2011 than before.

- The decadal scale variability was driven by Indian Ocean SST and East Asia low-level flow changes.

Keywords: Asian monsoon, Tropical cyclone, South China Sea monsoon, Indo-Pacific climate variability

\section{Introduction}

The Asian-Pacific monsoon is the largest monsoon system on earth that covers world's most densely-populated areas. The monsoon system extends from the Indian subcontinent eastward to Southeast and East Asia, and the

\footnotetext{
*Correspondence: mongminglu@ntu.edu.tw

${ }^{1}$ Department of Atmospheric Sciences, National Taiwan University, Taipei,

Taiwan (R.O.C.)

Full list of author information is available at the end of the article
}

Indo-Pacific maritime continent. The Asian monsoon rainy season commencement mainly consists of two phases (Wang and Linho 2002). The final stage of the commencement during the first phase is marked by the persistent rain surges over the South China Sea (SCS) in mid-May that reflects the establishment of a planetaryscale monsoon rainband extending from the Arabian Sea (ArS), through India to the Bay of Bengal (BOB), and reaches the SCS. The rain belts over Taiwan, southern China and Okinawa region also occurred during the first

\section{Springer}

(C) The Author(s) 2022. Open Access This article is licensed under a Creative Commons Attribution 4.0 International License, which permits use, sharing, adaptation, distribution and reproduction in any medium or format, as long as you give appropriate credit to the original author(s) and the source, provide a link to the Creative Commons licence, and indicate if changes were made. The images or other third party material in this article are included in the article's Creative Commons licence, unless indicated otherwise in a credit line to the material. If material is not included in the article's Creative Commons licence and your intended use is not permitted by statutory regulation or exceeds the permitted use, you will need to obtain permission directly from the copyright holder. To view a copy of this licence, visit http://creativecommons.org/licenses/by/4.0/. 
phase from early-May to mid-June (Cho and Lu 2021). The second phase is marked by the grand commencement of the Indian monsoon rain, Meiyu in the Yangtze River valley of China, Baiu in the main islands of Japan during the period from mid-June to mid-July, and finally reach the Korean Peninsula and north-eastern China during mid-July to mid-August (Lau 1992; Wang et al. 2001; Ding and Chan 2005; Ding et al. 2020).

The interdecadal variations of the first phase of the Asian-Pacific monsoons is a subject of active research. Kajikawa et al. (2012) found an advanced trend of the monsoon onset time over the $\mathrm{BOB}$ and the western North Pacific (WNP) revealed in the trends of the Asian monsoon rainfall and water vapor flux during 1979-2008 on a monthly mean basis. They showed an increasing (decreasing) trend of the rainfall in May (June) along $10^{\circ} \mathrm{N}$ in association with the advanced monsoon onset. They attributed the advanced onset and weakening of early summer Southeast Asian monsoon and western North Pacific monsoon to the changing heat contrast between the Asian landmass and the tropical Indian Ocean. The changing heat contrast may be resulted from the increased dust aerosol loading along the HimalayaTibetan Plateau that can enhance the heating in the mid-upper troposphere and strengthen the meridional thermal contrast (Lau and Kim 2006; Lau et al. 2006). On the other hand, a significant advance in the South China Sea summer monsoon (SCSSM) onset dates around 1993/1994 was reported by Kajikawa and Wang (2012). They found that before the mid-1990s when the onset was relatively late the commencement of the summer convection over the SCS was primarily determined by the northward seasonal march of the ITCZ. After the mid-1990s when the onset was advanced for about two weeks the commencement of the SCS convection was enhanced by the northwestward-moving tropical disturbances from the equatorial western Pacific. The SCS and Philippine Sea SSTs also increased significantly after the mid-1990s. The number of TCs that passed through the SCS and Philippine Sea was about doubled during 19942008 compared with those occurring during 1979-1993. They suggested that the advanced SCSSM onset is rooted in the decadal change of the SST over the equatorial western Pacific. In a later report, Xiang and Wang (2013) showed that the advanced monsoon onset also occurred over ArS and BOB after 1999. The results of their numerical experiments with an atmosphere-ocean coupled climate model suggested that the advanced Asian summer monsoon onset can be attributed to the shift to the grand La Niña-like climate mean state in the Pacific basin. The La Niña-like mean state is characterized by the enhanced equatorial Pacific SST zonal gradients that can enhance the westward propagating Rossby waves and its interaction with the asymmetric background mean states in the Indian Ocean (IO) and WNP. The wave and mean state interaction can enhance the east-west heating contrast between the WNP and IO and further enhance the Northern Hemispheric perturbations and westerly winds (Lyon et al. 2014). Therefore, they advocated that the advanced monsoon onset in the ArS and $\mathrm{BOB}$ is governed by the equatorial Pacific SST zonal gradients, while the SCS is strongly influenced by the abrupt SST warming near the Philippine Sea. Liu et al. (2016) supported that view that the grand La Niña-like modulation on the spring tropical temperature can enhance the upper-level pumping effect over the SCS during the decade after 1993/1994 (1994-2014) and lead to the advanced monsoon onset.

A change of the early summer large-scale environment over the WNP around the year 2000 was reported by Tu et al. (2011). They found the intense typhoons (category 4 and 5) that seldomly occurred in May before 2000 became much more frequent in the 2000s (2000-2009). The change was not detected in June. They attributed the increase of intense typhoons in May to the increased tropospheric water vapor and greater water vapor in the mid-troposphere. $\mathrm{Xu}$ and Wang (2014) found that the WNP TC power dissipation index (PDI) in May showed a remarkable increasing trend in the time series from the pre-1999 years (1979-1999) to the post-1999 years (2000-2011) over the TC genesis region $\left(110^{\circ} \mathrm{E}\right.$ to $160^{\circ}$ $\mathrm{E}, 5^{\circ} \mathrm{N}$ to $20^{\circ} \mathrm{N}$ ). Both TC numbers and TC intensity showed a sharp increase during the post-1999 years. They attributed the higher TC intensity to the increased maximum potential intensity and reduced $\mathrm{TC}$ ambient vertical wind shear. They concluded that the decadal changes in background conditions over the WNP are the results of the enhanced summer monsoon in May over both South Asia and SCS. On the other hand, Huangfu et al. (2019) found that an El Niño-Southern Oscillation (ENSO) and the stratospheric quasi-biennial oscillation (QBO) combined effect can influence the cross-tropopause shear over the equatorial central Pacific $\left(0^{\circ}\right.$ to $5^{\circ} \mathrm{N}$, $160^{\circ}$ to $180^{\circ} \mathrm{E}$ ) in May, which can subsequently modulate the eastward extension of monsoon trough (MT) and the TC genesis environment. TC genesis is slightly enhanced in the May following La Niña events and the QBO west phase, while it is suppressed following the decaying El Niño events and the QBO easterly phase.

The early summer TC influence on the Mei-yu season (May-June) Taiwan rainfall was explored in Cho and $\mathrm{Lu}$ (2021). They reported that no significant relationship between TC and Taiwan Mei-yu rainfall was detected, and noted a decadal-scale contrast in the frequency of TCs that entered into peripheral areas of Taiwan surrounding the coastline by a $300-\mathrm{km}$ distance (Fig. 8 in 
Cho and Lu 2021). The contrast is consistent with previous findings that more pre-monsoon (before mid-May) TCs was observed during the post-1999 years (19992019) than during the pre-1999 years (1978-1998). Since Taiwan Mei-yu is a part of the Asian-Pacific monsoon system, it is important to understand the interdecadal changes of the monsoon onset and WNP TC activity in order to understand Mei-yu variability in and around Taiwan.

The focus of the present paper is on the early summer (May-June) season, which is the first phase of the AsianPacific monsoon rainy season and the pre-season of the WNP TC active season. We will document the interdecadal changes of the SCS TC activity and the associated large-scale environment to address the following three questions. After seeing the increase during the decade before 2011, we want to know how did the WNP TC genesis frequency in May evolve during the most recent decade (2011-2020)? After seeing the advanced onset during the decade before 2011, we want to know how did the Asian-Pacific monsoon onset change with time during the most recent decade (2011-2020)? Can we find significant variability in the Asian-Pacific summer monsoon evolution during the past decade (2011-2020) and pre-season WNP TC activity? The paper is arranged as follows. The data and methodology are described in Sect. 2. Section 3 describes the WNP TC activity in May and June, the northward progression of the monsoon rain-bands, and tropical deep convection and circulation during the monsoon transition period. Some discussions on the decadal variations of the IO and Pacific SSTs and TC activities are presented in Sect. 4. Section 5 is the summary and conclusions. The results of this study can improve understanding of the relationship between regional climate, TC, and the Asian-Pacific monsoon evolution during the monsoon transition period in early summer.

\section{Data and methodology}

The large-scale climate data used in this study include the ECMWF Reanalysis v5 (ERA5) data (Hersbach et al. 2020), NASA's Global Precipitation Climatology Project (GPCP) version2.2 pentad rainfall data (Huffman et al. 2009), NOAA's Climate Prediction Center (CPC) MORPHing technique $(\mathrm{CMORPH})$ precipitation v1.0 biascorrected data with the spatial resolution of $0.25^{\circ} \times 0.25^{\circ}$ longitude-latitude (Xie et al. 2017), and the interpolated daily Outgoing longwave radiation (OLR) version 1.2 with the spatial resolution of $1^{\circ} \times 1^{\circ}$ (Lee 2011). For SST data, the NOAA Extended Reconstructed Sea Surface Temperature (ERSST v5; Huang et al. 2017) of monthly and $2^{\circ} \times 2^{\circ}$ horizontal resolution is used.
The TC data used in this study is the best track data produced by Regional Specialized Meteorological Center (RSMC), Tokyo, Japan (http://www.jma.go.jp/jma/jmaeng/jma-center/rsmc-hp-pub-eg/besttrack.html). The RSMC Tokyo-Typhoon Center maintains near real-time updates of the JMA TC best track data. TC in the present study refers to tropical storms and typhoons that have the maximum sustained wind speed of the surface wind (VMAX) of 34 knots or higher (wind speed $>34$ knots) during the storm's entire lifetime. The TC genesis location is identified as the latitude and longitude of the first record of VMAX that exceeds 34 knots. The passage frequency maps presented in Sect. 3 are based on the current 30 years of climate from 1991 to 2020. The passage frequency maps are calculated at each pixel of the $2.5 \times 2.5^{\circ}$ of latitude and longitude grid boxes. The vertical wind shear presented in this study is calculated as the total wind speed at $200 \mathrm{hPa}$ minus the wind speed at $850 \mathrm{hPa}$.

\section{Results}

\subsection{WNP and SCS TC activity during May and June}

The WNP and SCS TC can occur in any month of a year. The peak season is from July to November that counts $80 \%$ of the sum of all TC life spans in hours during 60 years from 1961 to 2020 (Fig. 1a). The quiet season is from January to March which counts for only $3.2 \%$ of the annual sums. The transition months from April to June counts $12.6 \%$ of the annual sums. In this study, the months of April-June is named as the "pre-season" of the WNP and SCS TC active season. Figure 1b shows an interesting decadal-scale variation pattern of the preseason TC genesis frequency. During the 6 decades from 1961 to 2020, the period of 1971-1980 is the decade with the most frequent TC genesis, while the period of 19912000 is the decade with the least frequent TC genesis. However, the April-May TCs had the minimum genesis frequency during the decade of 2011-2020.

The WNP and SCS TC passages during the transition season can be clearly seen in the monthly maps presented in Fig. 2 based on the 40-year (1981-2020) TC data in April, May and June. TCs tend to form in a southeastnorthwest oriented narrow zone from the west Pacific warm pool to the SCS. Over the SCS and Philippine Sea region $\left(110^{\circ} \mathrm{E}\right.$ to $130^{\circ} \mathrm{E}, 10^{\circ} \mathrm{N}$ to $\left.20^{\circ} \mathrm{N}\right)$ the $\mathrm{TC}$ activity expands northward with time. The TC genesis locates in April is similar to that in May but the frequency in April is much smaller than in May. In order to focus on May which is the onset month of the Asian summer monsoon, the April TCs will not be discussed in the rest of the paper.

The interannual variations of the TCs in Taiwan-Philippine area are summarized in the area mean frequency 

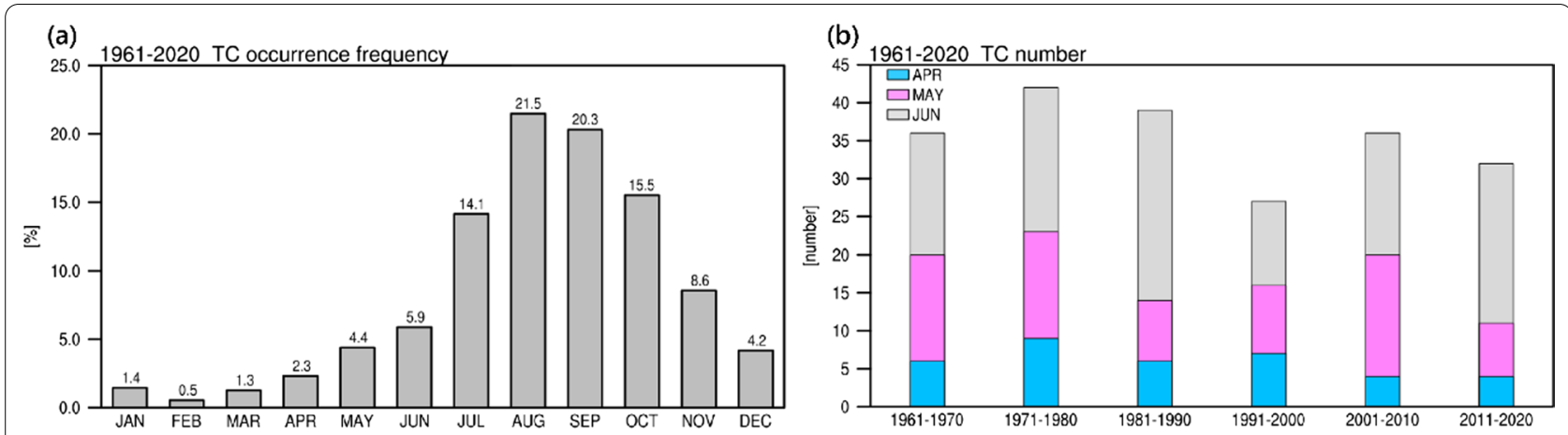

Fig. 1 a Monthly percentage distribution of tropical cyclones (TC) frequency in the western North Pacific and South China Sea $\left(100^{\circ} \mathrm{E}-180^{\circ} \mathrm{E}\right.$, $0^{\circ}-40^{\circ} \mathrm{N}$ ) over the period of 1961-2020. Numbers above each gray bar indicate the percentage in each month. $\mathbf{b}$ The sums of TC numbers in April, May and June (shown in blue, pink, and gray) in six decades over the period of 1961-2020

of the TC passage over two regions, the SCS $\left(110^{\circ} \mathrm{E}\right.$ to $120^{\circ} \mathrm{E}, 10^{\circ} \mathrm{N}$ to $\left.20^{\circ} \mathrm{N}\right)$ and the Philippine Sea and west Pacific warm pool (PSWP) $\left(120^{\circ} \mathrm{E}\right.$ to $150^{\circ} \mathrm{E}, 10^{\circ} \mathrm{N}$ to $20^{\circ}$ $\mathrm{N})$, in May and June from 1981 to 2020. Figure 3 shows a consistent feature to the previous findings (Kajikawa and Wang 2012; Xiang and Wang 2013; Xu and Wang 2014) that the WNP TC activity in May shows a remarkable increase from the pre-1999 years to the post-1999 years, but the similar increase is not observed in June. The TC passage was less frequent during the period of 19912000 than the period of 2001-2010 (Fig. 3a, b). However, a dramatic change occurred after the year 2009. Figure 3a shows that the period of 2010-2019 was the quietest 10 years. It is more extreme than the earlier relatively quiet period from 1991 to 2000 as what we see in Fig. 3a there is absolutely no TC activity recorded during the entire 10-year period. Over the PSWP area (Fig. 3c, d) the period of 2010-2019 was also a quiet period, but with three $(2011,2012,2015)$ years that still had TC passage recorded it is less extreme compared with the quietness over the SCS. Different from the May quietness, Fig. 3b shows that during the period of 2010-2019 the TC activity over the SCS is active in June. The May and June contrast is less sharp over the PSWP region. The longest quiet period is the four-year window (20142017) in Fig. 3d, where no TC activity was detected. In summary, the TC activity during May and June in general was weakened after 2014 over the PSWP (Figs. 1b, 3c, d). It is worth mentioning that an earlier quiet period of 1996-2000 over the SCS reported by many authors (e.g. Lu et al. 2020 and references therein) can also be identified in Fig. 3b.

The interdecadal difference of the TC passage density between the after 2011 decade (2011-2020) and the before 2011 decade (2001-2010) in May and June are respectively presented in Fig. $4 \mathrm{a}$ and $\mathrm{b}$. The contrast between these two decades is consistent with Fig. 3 that the SCS saw decreased (increased) TC activity in May (June) from the decade before 2011 to the decade after 2011. In the PSWP region during the decade after 2011 the June TC activity was more active to the west of $130^{\circ}$ E over the Philippine Sea $\left(120^{\circ} \mathrm{E}\right.$ to $130^{\circ} \mathrm{E}, 10^{\circ} \mathrm{N}$ to $20^{\circ}$ $\mathrm{N})$ during the recent decade, while to the east of $130^{\circ} \mathrm{E}$ in June the TC activity was less active. It is interesting to see the east-west contrast pattern over both the SCS and the PSWP in Fig. 4b, which shows the area with more active TC passage is located to the west of the area of less TC activity. The contrast is related to the transition of the Asian-Pacific monsoon from spring to summer that we will discuss in the next section.

\subsection{Seasonal evolution and decadal changes}

The April to June evolution of the rainfall and wind patterns over the Asian-Pacific monsoon region is presented in Fig. 5. Over the equatorial region, we see the precipitation is mainly over Indonesia maritime continent. The equatorial rain is strongest during April and became weaker in the following two months. Over the western Pacific $\left(130^{\circ} \mathrm{E}-170^{\circ} \mathrm{E}\right)$ the rainfall center gradually shifts westward from $160^{\circ} \mathrm{E}-170^{\circ} \mathrm{E}$ in April to $130^{\circ} \mathrm{E}-150^{\circ} \mathrm{E}$ in June. Over the subtropical region to the north of $10^{\circ}$ $\mathrm{N}$ a clear rain band oriented in the southwest-northeast direction intensified during these three months. The most pronounced rainfall center in June is over the $\mathrm{BOB}$. In the upper level at $200 \mathrm{hPa}$ we see the anticyclonic circulation center over Southeast Asia and the SCS in April (Fig. 5d). The anticyclonic circulation center gradually moved northwestward to the northern $\mathrm{BOB}$ and the Himalayas in May. Note that the ridge of the upper-level anticyclone is located along the latitude of about $15^{\circ} \mathrm{N}$ in May (Fig. 5e) and along $25^{\circ} \mathrm{N}$ in June (Fig. 5f). Over the SCS and PSWP from April to June the vertical wind shear weakened with the large-scale upper-level wind evolution. On the other hand, the positive low-level vorticity 
(a)

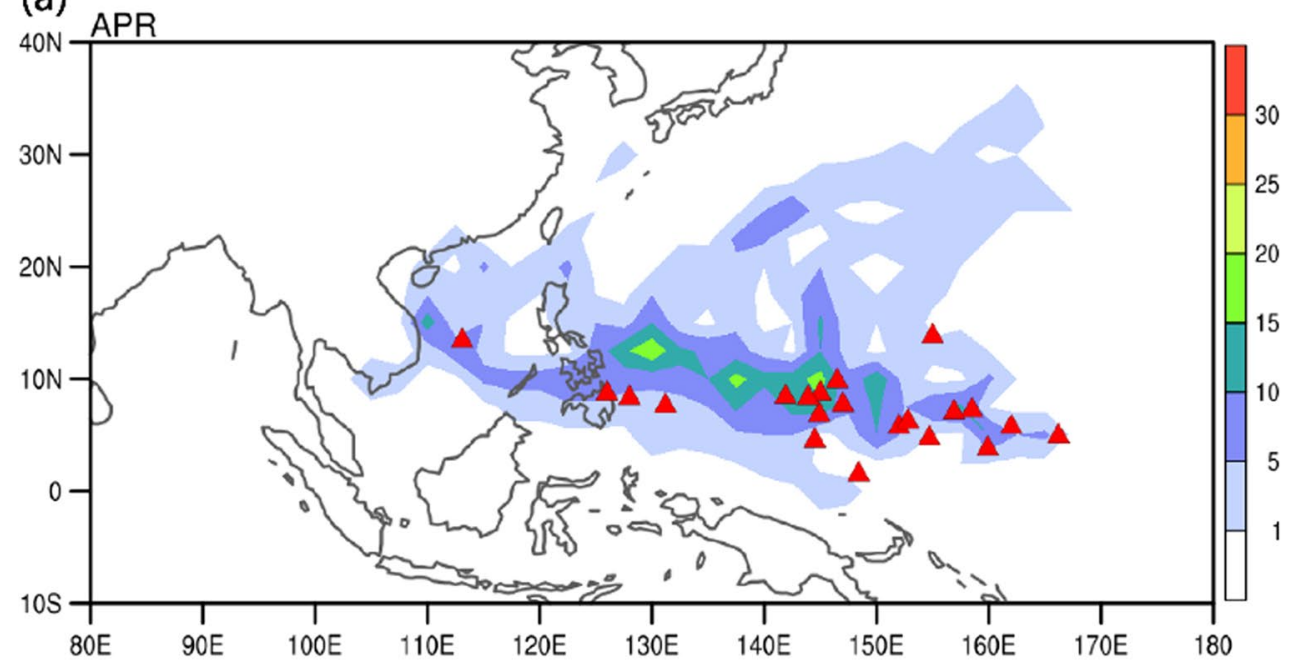

(b)

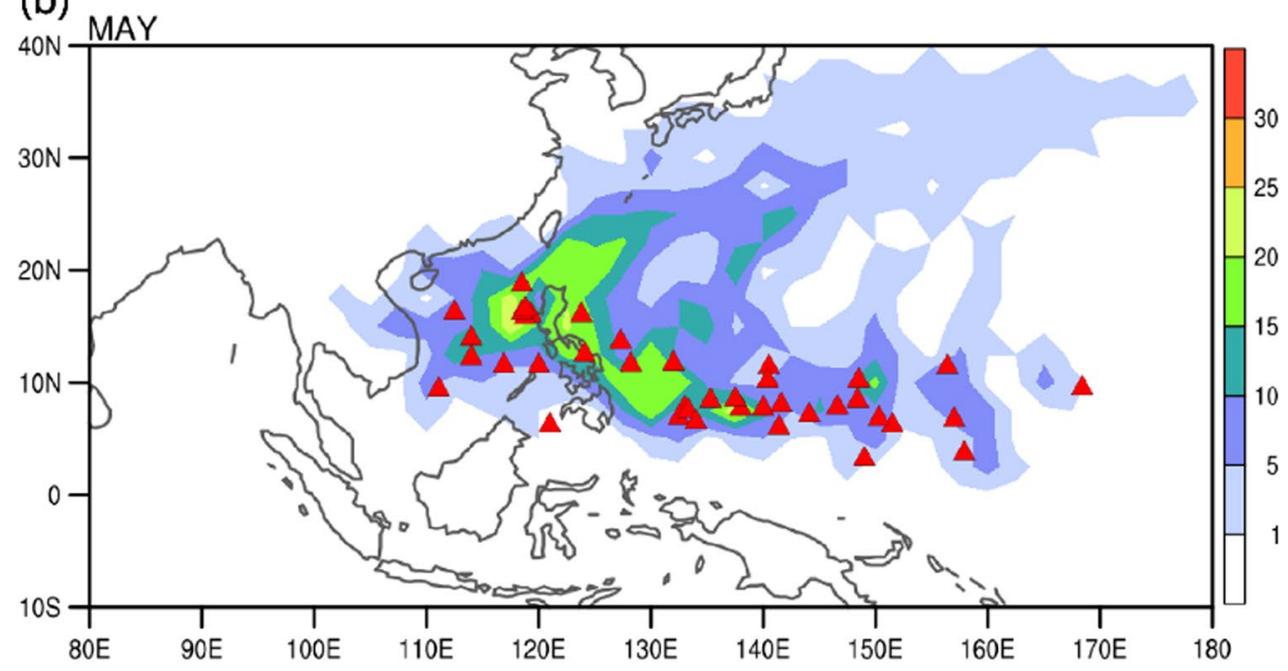

(c)

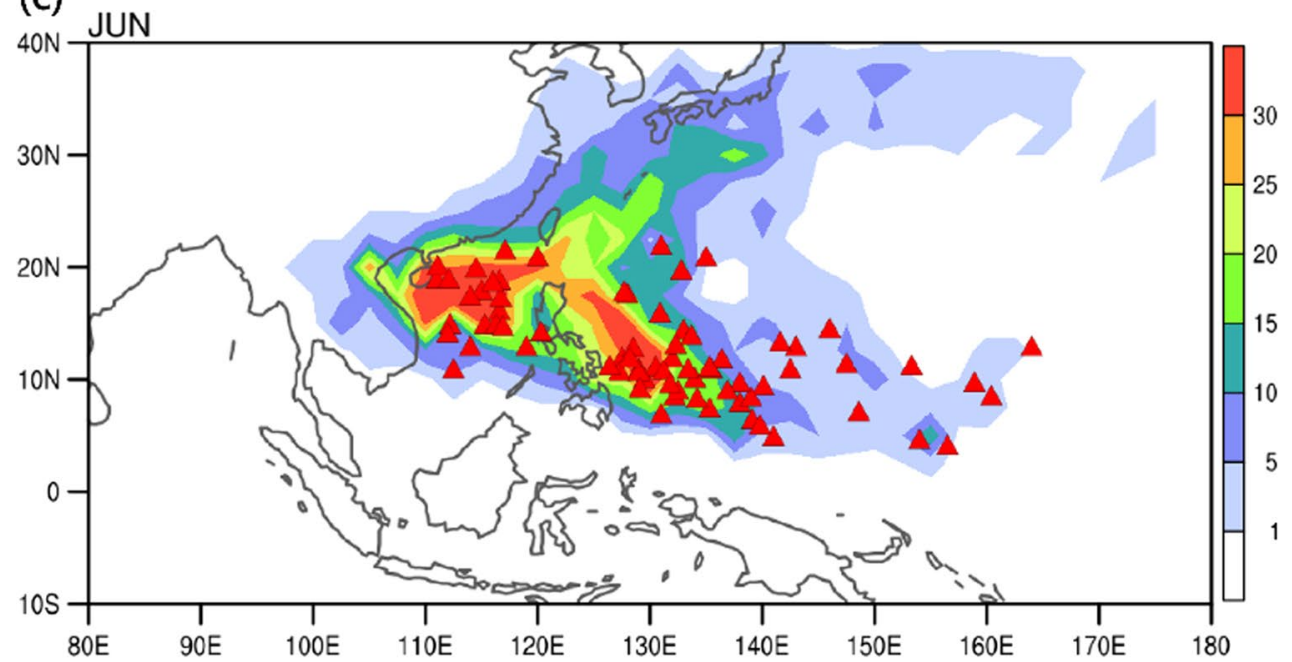

Fig. 2 The accumulation of TC passage frequency in each $2.5^{\circ} \times 2.5^{\circ}$ grid area during 1981-2020 for a April, b May, and $\mathbf{c}$ June. The TC genesis locations are indicated by the red triangles 

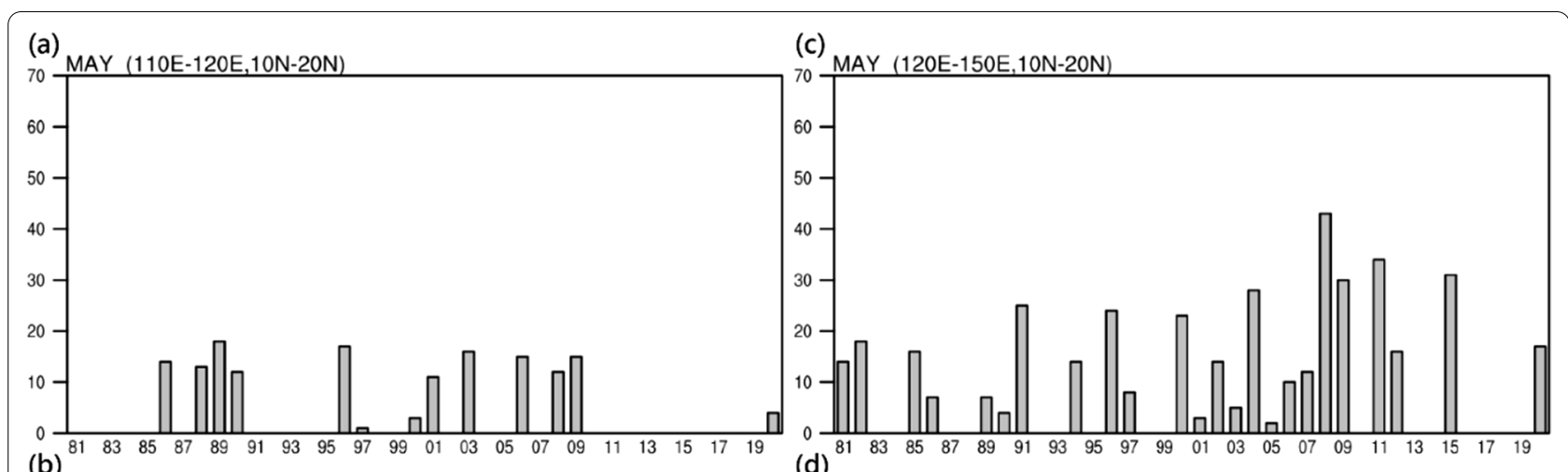

(b) JUN (110E-120E.10N-20N)

(d) JUN (120E-150E,10N-20N)
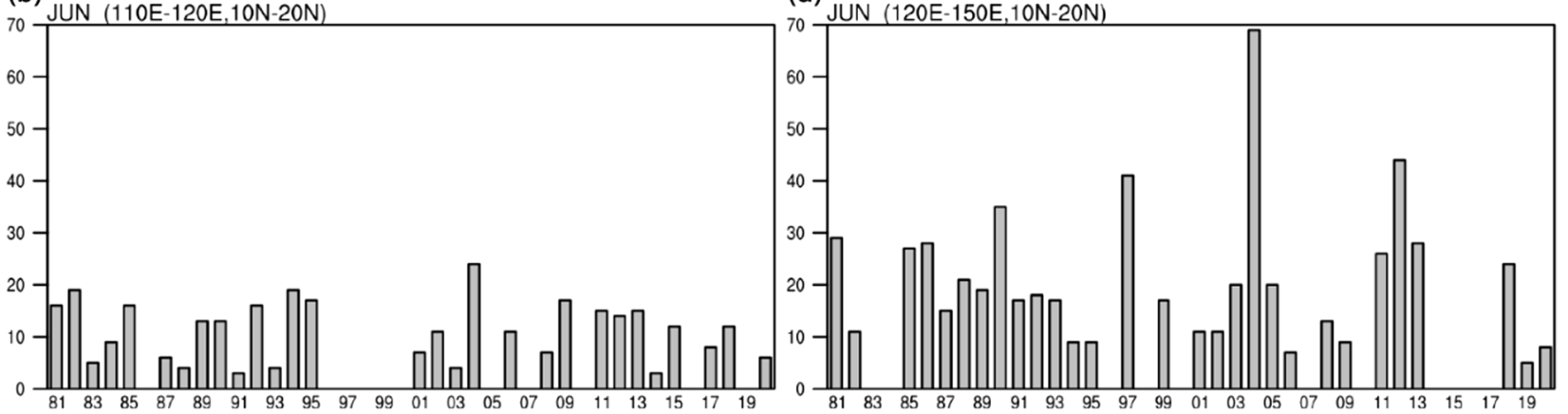

Fig. 3 Variation of TC passage frequency during 1981-2020 for May (a, c) and June (b, d) over two regions: $\mathbf{a}, \mathbf{c} 110^{\circ} \mathrm{E}-120^{\circ} \mathrm{E}, 10^{\circ} \mathrm{N}-20^{\circ} \mathrm{N}$, and $\mathbf{b}, \mathbf{d}$ $120^{\circ} \mathrm{E}-150^{\circ} \mathrm{E}, 10^{\circ} \mathrm{N}-20^{\circ} \mathrm{N}$

shifted from the latitudes near the equator to around $15^{\circ}$ $\mathrm{N}$ in June. The seasonal evolution of the low-level vorticity and vertical wind shear is consistent with the evolution of TC genesis and passage presented in Fig. 2.

To find out whether the Asian-Pacific monsoon onset showed advancement after 2011, we checked the monthly tendency of precipitation and $850 \mathrm{hPa}$ wind during three periods: 1981-2000, 2001-2010 and 2011-2020. Figure $6 \mathrm{a}-\mathrm{c}$ are the tendency evolved from April to May and Fig. $6 \mathrm{~d}-\mathrm{f}$ are the tendency evolved from May to June. Using the 20-year (1981-2000) mean as a reference for contrasting the two decades before and after 2011, we found that from April to May the evolution amplitude of the southwest-northeast elongated monsoonal rain bands are strongest during the period of 2001-2010 (Fig. 6b) compared with the other two periods in Fig. 6a and c. The associated wind tendency over the ArS and the SCS is also largest during 2001-2010. However, from May to June the evolution amplitude of the southwest-northeast elongated monsoonal rain bands during the period of 2001-2010 (Fig. 6e) is the weakest. The largest evolution tendency appears after 2011 (Fig. 6f) and the evolution includes both wet and dry contrast between May and June. The wet tendency appears over the major monsoon wet regions such as the ArS, BOB, SCS, PSWP and the Mei-yu front near the lower valley of Yangtze River and
Japan. The dry tendency region is located to the south of the wet tendency region. The contrast implies that the seasonal transition after 2011 did not advance, but the before and after the monsoon onset large-scale rainfall and circulation differences represented by the May to June tendency was enlarged after 2011. The sharper transition after 2011 over the SCS and the Philippine Sea is consistent with more frequent TC passages in June presented in Fig. 3c.

The inter-decadal changes of the large-scale condition for the SCS TC activity is further investigated by comparing the seasonal transition tendency of the influential factors to TC genesis, such as the low-level $(850 \mathrm{hPa})$ vorticity, the vertical wind shear measured by the total wind speed difference between lower- and upper-levels $(850 \mathrm{hPa}$ and $200 \mathrm{hPa})$, and the lower-level circulation patterns. Figure 7a is the April to May tendency based on the 30 years (1991-2020) climatology and Fig. 7b is the May to June tendency. Focusing on the SCS we see from April to June the vorticity tendency is positive, which means that the seasonal transition of the low-level circulation is favorable for TC genesis. Over the northern SCS, the vertical wind shear shows a weakening tendency from April to May but slight intensification from May to June. It suggests that the vertical wind shear over the SCS is on average weakest in May in the northern 


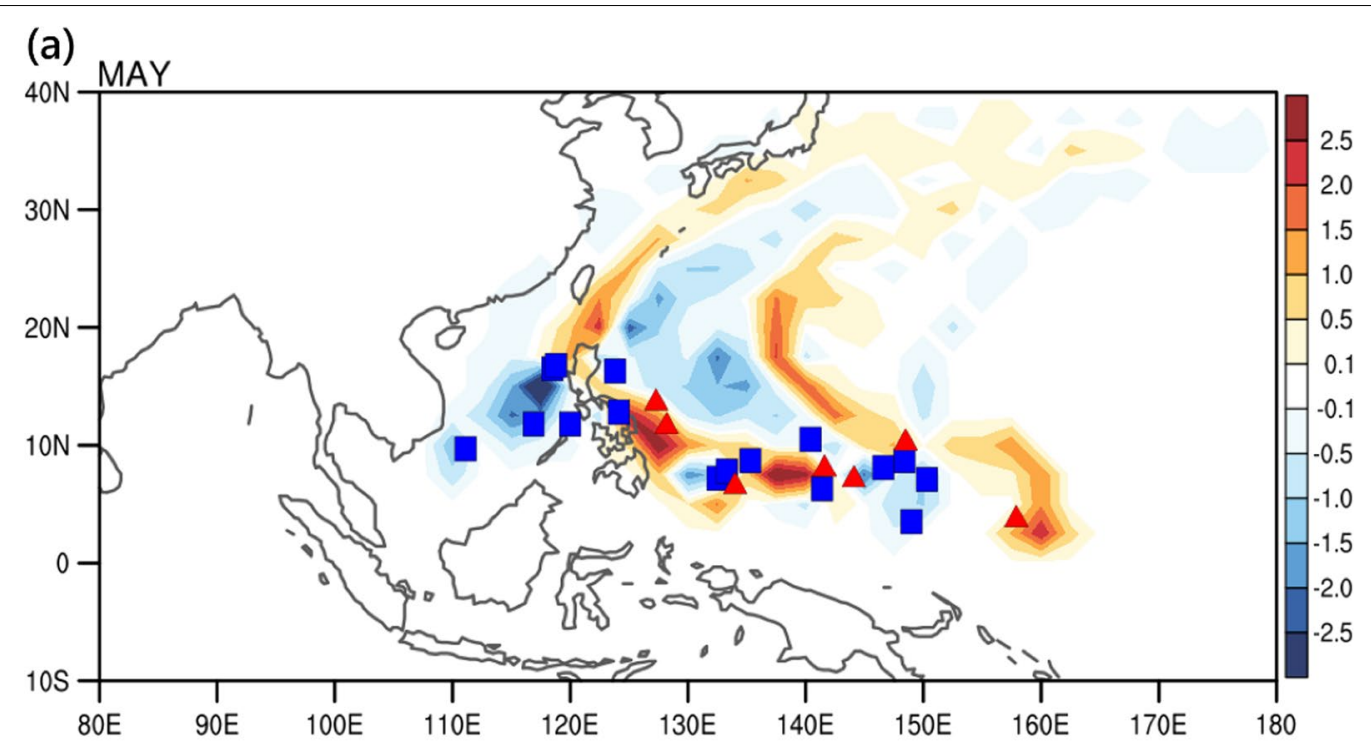

(b)

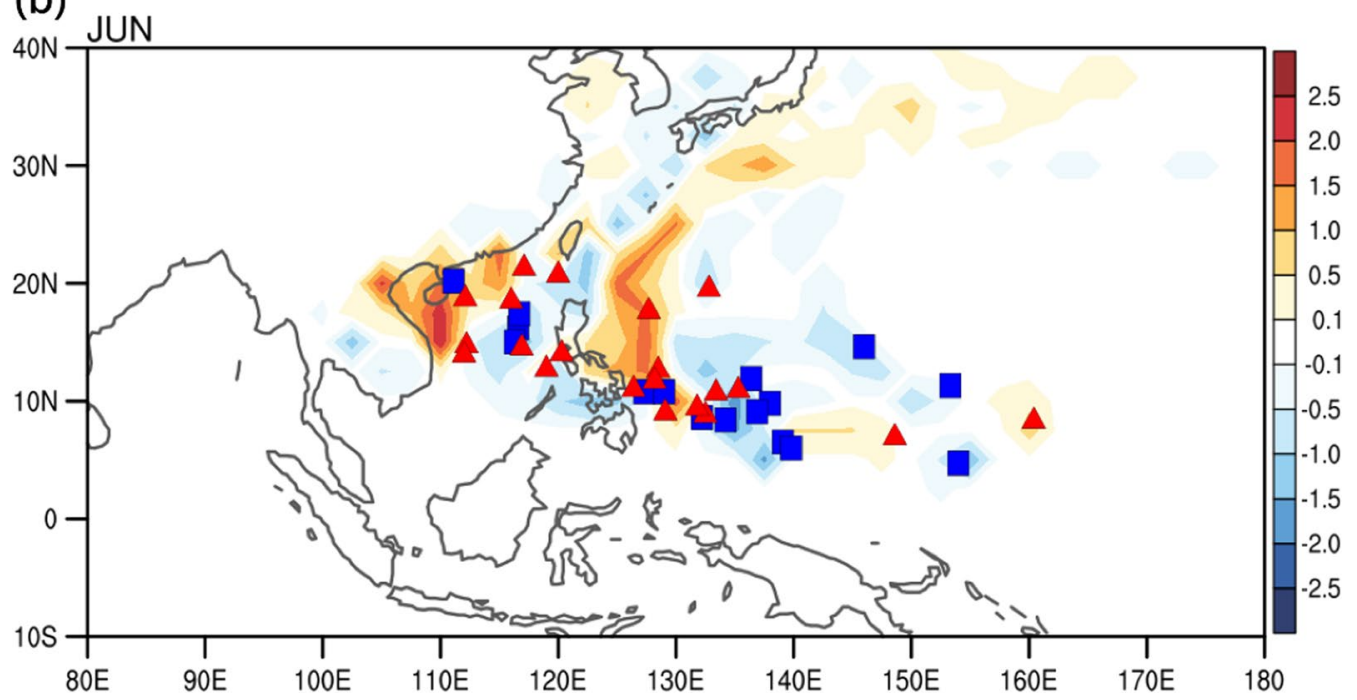

Fig. 4 The tropical cyclones (TC) passage frequency differences for the period of 2011-2020 minus 2001-2010 in a May and $\mathbf{b}$ June. The red triangles and blue squares denote the TC genesis locations during 2011-2020 and 2001-2010, respectively

part, in particular to the north $15^{\circ} \mathrm{N}$. The western North Pacific sees intensification of negative vorticity from May to June. It reflects the rapid development of the western Pacific subtropical high pressure system during June. In short, the seasonal transition of the circulation pattern over the SCS and the land area of Southeast and East Asia shows a coherent intensification of the cyclonic circulation pattern over East Asia and the SCS. The interdecadal changes of the seasonal transition tendency are represented by the difference between the decade before and after 2010 (Fig. 7c-d). In Fig. 7c to the south of $20^{\circ}$ $\mathrm{N}$ the decadal difference shows that the signs of the lowlevel wind, vertical wind shear and low-level vorticity are all opposite to the seasonal tendency in Fig. 7a. It suggests that the seasonal transition from April to May in the later decade is weaker than the earlier decade. In contrast to the tropics, in the extratropical region to the north of $20^{\circ}$ $\mathrm{N}$ in particular over land, the signs of the decadal difference are the same as the seasonal tendency in Fig. 7a. It suggests the seasonal transition from April to May in the later decade is stronger than the earlier decade. The May to June transition in Fig. $7 \mathrm{~d}$ shows that to the south of $20^{\circ}$ $\mathrm{N}$ the decadal change is in the opposite direction to the April to May tendency (Fig. 7c) which suggests that the advanced Asian monsoon onset during the earlier decade did not continue to the later decade. It is interesting to 


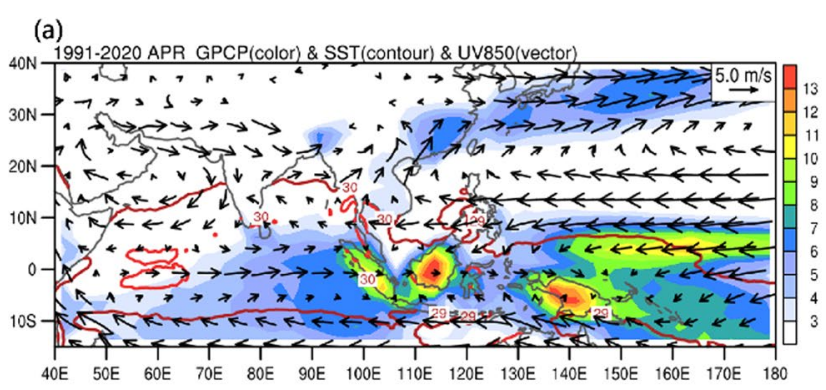

(b)

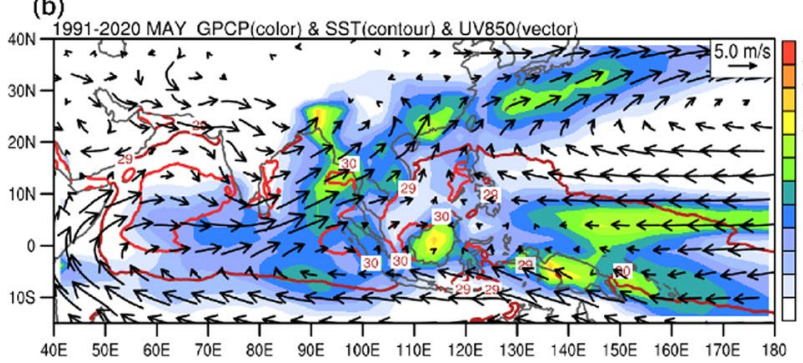

(c)

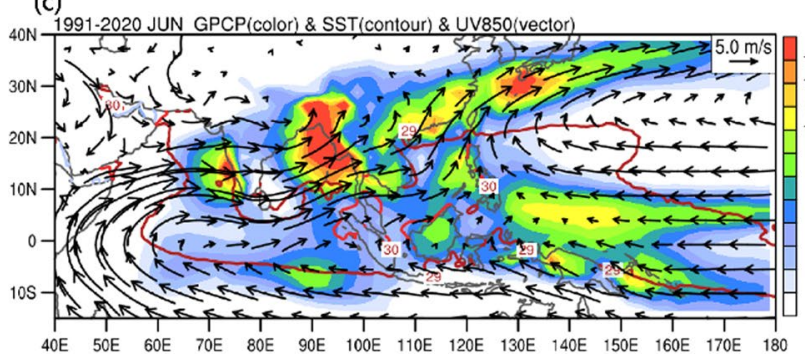

(d)

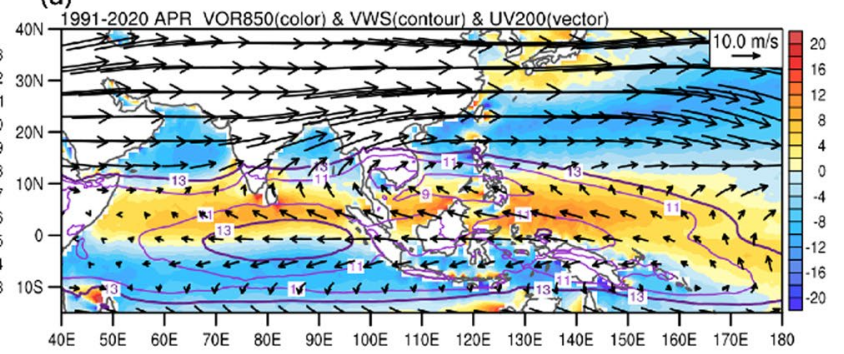

(e)

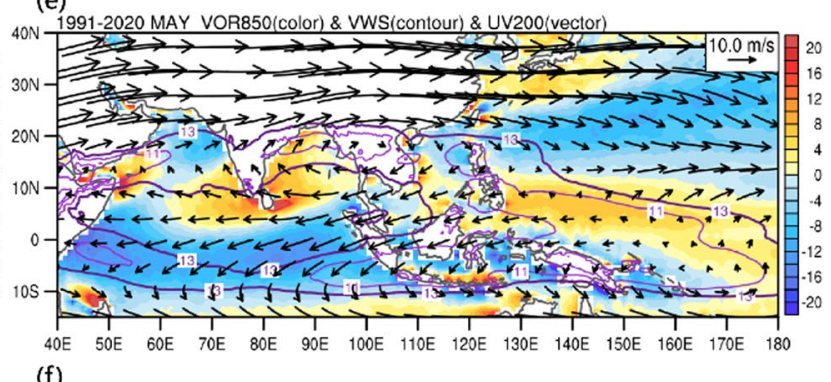

(f)

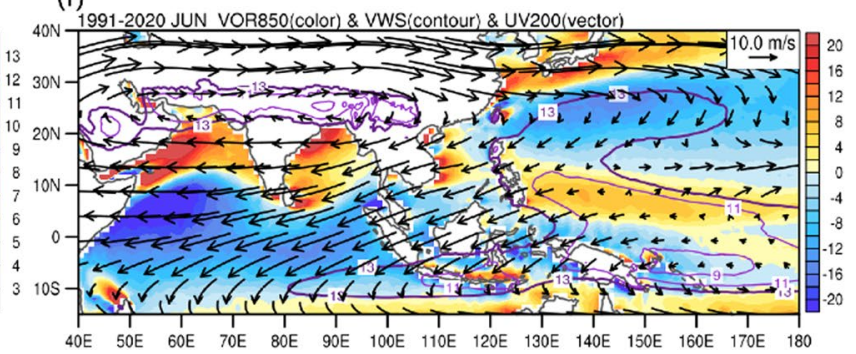

Fig. 5 Climatological monthly mean of large-scale environment in April (a, d), May (b, e), and June (c, f) over the period of 1991-2020. a-c

Precipitation (shading, $\mathrm{mm}_{\text {day }}{ }^{-1}$ ), SST (contours, ${ }^{\circ} \mathrm{C}$ ) and $850 \mathrm{hPa}$ winds (vectors, $\mathrm{ms}^{-1}$ ). The contour interval is $1^{\circ} \mathrm{C}$ and the lines denote SST higher than $29^{\circ} \mathrm{C}$. $\mathbf{d}-\mathbf{f} 850 \mathrm{hPa}$ relative vorticity (shading, $10^{-5} \mathrm{~s}^{-1}$ ), vertical wind shear (contours, ms ${ }^{-1}$ ) and $200 \mathrm{hPa}$ winds (vectors, ms ${ }^{-1}$ ). The contour interval is $1 \mathrm{~ms}^{-1}$ and the lines denote vertical wind shear smaller than $13 \mathrm{~ms}^{-1}$

note that the signs of all variables plotted in Fig. 7d, on average, are the same as in Fig. $7 \mathrm{~b}$ in the tropical region and over the Pacific. It suggests that the monsoon transition from May to June is sharper and stronger during the past decade of 2011-2020. It can result in above normal TC activity over the SCS and more intensive rainfall events over the Yangtze River and Japan in June and July.

\subsection{Northward progression of the monsoonal rain bands}

The northward progression of the monsoonal rainband can be identified in the latitude-time cross sections (Fig. 8). The progression is particularly clear over the longitudinal bands of the marginal oceans such as the ArS, BOB and SCS, where the monsoon onset signals are strong. The longitudinal bands of the PSWP is a region of active TC activity. Knowing the decadal changes of the seasonal progression of the rain bands can help us to understand why the TC activity in May over the SCS was the weakest during the decade of 2011-2020. Figure 8a shows a steady northward progression of the major rain band from April to June over the ArS. The rainband in April and early May bifurcates into two rainbands after late May where one reaches $10^{\circ} \mathrm{N}$ to $20^{\circ} \mathrm{N}$ in June and the other stays near the equator at $5^{\circ} \mathrm{S}$ to $10^{\circ} \mathrm{S}$. Similar double rainband phenomenon also appears over the BOB (Fig. 8b) but with overall much larger rainfall amount and much wetter subtropical rain to the north of $15^{\circ} \mathrm{N}$ than the near-equator rain at $5^{\circ} \mathrm{S}$ to $10^{\circ} \mathrm{S}$. The transition from the moderate to the abundant rain marks the transition from the developing to mature stages of the Asian summer monsoon. The spatial distribution of monsoonal rainfall is illustrated in Fig. 5c. The seasonal progression of the monsoonal rainband over the SCS is very different from the ArS and BOB. Figure 8c shows two rain bands during April with one over the equator and the other over extratropical region to the north of $25^{\circ} \mathrm{N}$. The separation of these two rainbands becomes less clear after mid-May and merges to form a large wet region from the equator to the subtropics in June. Note that we can actually find three wet zones in Fig. 5c in mid-June at the latitudes of 


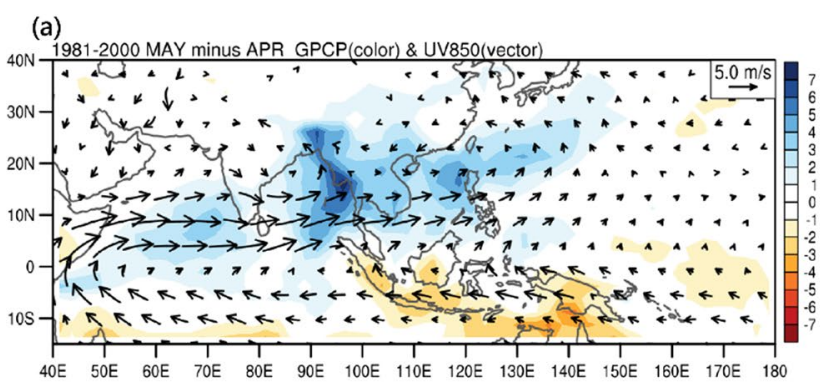

(b)

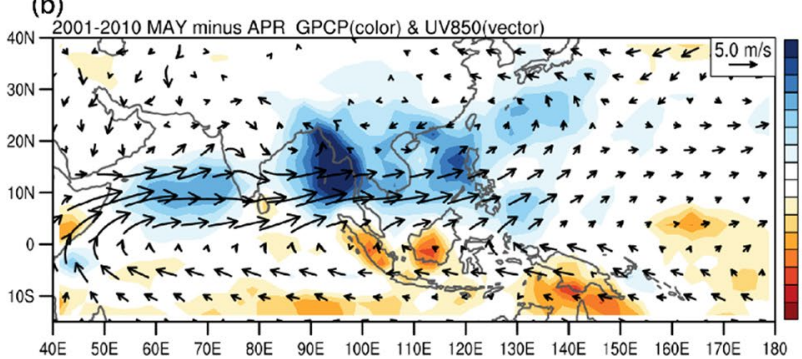

(c)

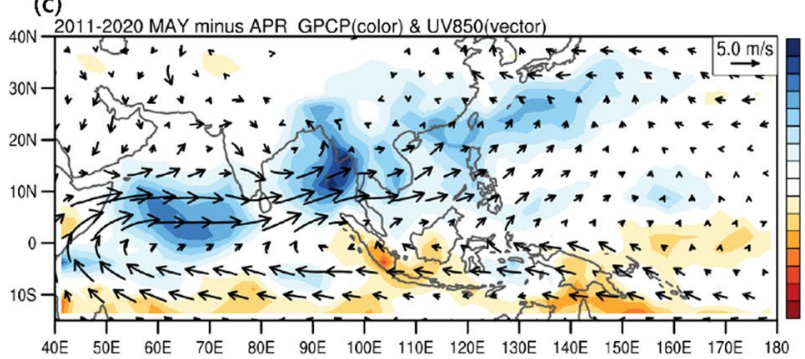

(d)

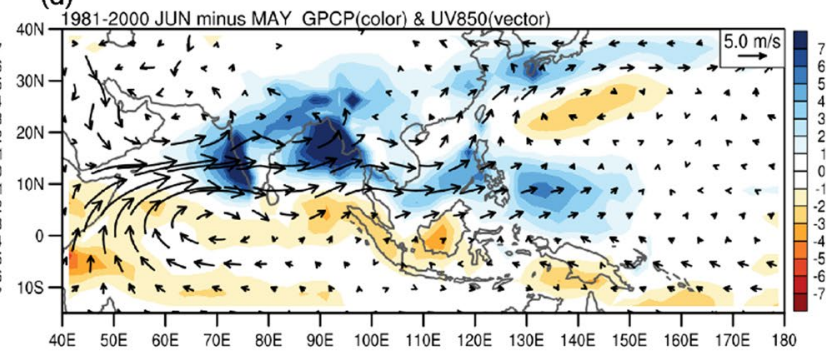

(e)

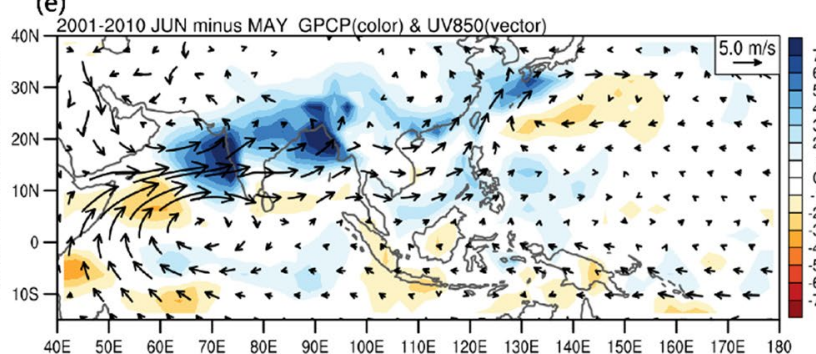

(f)

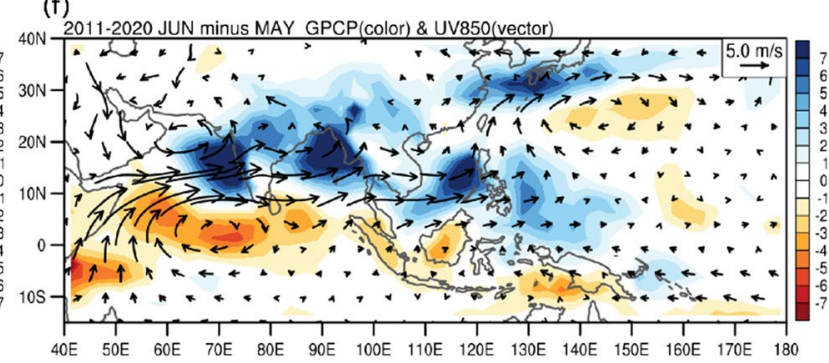

Fig. 6 The monthly tendency of precipitation (shading, $\mathrm{mm}$ day ${ }^{-1}$ ) and $850 \mathrm{hPa}$ winds (vectors, $\mathrm{ms}^{-1}$ ) calculated as the difference between May and April (May minus April) (left panel) and the difference between June and May (June minus May) (right panel) for a, d 1981-2000, b, e 20012010, and c, f 2011-2020, respectively

around $20^{\circ} \mathrm{N}, 10^{\circ} \mathrm{N}$ and the equator. The disappearance of the relatively dry zone centered along $15^{\circ} \mathrm{N}$ marks the onset of the SCSSM. The Mei-yu rain band over Taiwan and South China is shown as the wet region to the north of $25^{\circ} \mathrm{N}$. The wet region over the central SCS near the west coast of the Philippines can also be clearly identified in Fig. 5c. As it is shown in Fig. 5c that the wet zone near the equator is over Borneo. The rain band progression over the PSWP latitudes is shown in Fig. 8d. Different from the Asian monsoon, the seasonal transition over the western Pacific during the period from April to June is characterized by a gradual northward shift of the rain bands near the equator. In April more rain appeared to the south of the equator than to the north of the equator, which is in contrast to the pattern in June that to the north is wetter than to the south of the equator. The persistent dry condition over $10^{\circ} \mathrm{N}$ to $20^{\circ} \mathrm{N}$ is part of the western Pacific subtropical high (WPSH) (Fig. 5c) that shows northward progression during late June.

The decadal change of the northward progression of the monsoonal rainbands during two decades before and after the year 2011 can be identified in Fig. 9. Figure $9 \mathrm{a}-\mathrm{d}$ (Fig. 9e-h) show the latitude-time cross sections of the pentad anomalies of rainfall amount and the wind vectors at $850 \mathrm{hPa}$ averaged over the periods of 2001-2010 (2011-2020). Using Fig. 8 as a reference, we can find that the anomaly patterns over the ArS (Fig. 9a) and BOB (Fig. 9b) indeed show advanced monsoon onset pattern in particular to the north of $10^{\circ} \mathrm{N}$ in early May. Although over the ArS the rainfall during May is above normal, the advanced onset marked by the northward progression of the rainband was not clear in the time-latitude cross section in the latter decade (Fig. 9e). During June, Fig. 9e shows that the wet and dry contrast is sharper than the 30-year climatology. The contrast pattern is formed by two rainbands along $5^{\circ} \mathrm{S}$ and $15^{\circ} \mathrm{N}$ and one relatively dry band from $5^{\circ} \mathrm{N}$ to $10^{\circ} \mathrm{N}$. The enhanced contrast can be identified in Fig. 9f-g during the earlier period in May and even April over the SCS. Figure 9h shows that over the WNP the rainfall anomalies show strong sub-monthly oscillations with wet periods near the equator $\left(0^{\circ}\right.$ to $\left.10^{\circ} \mathrm{N}\right)$ 


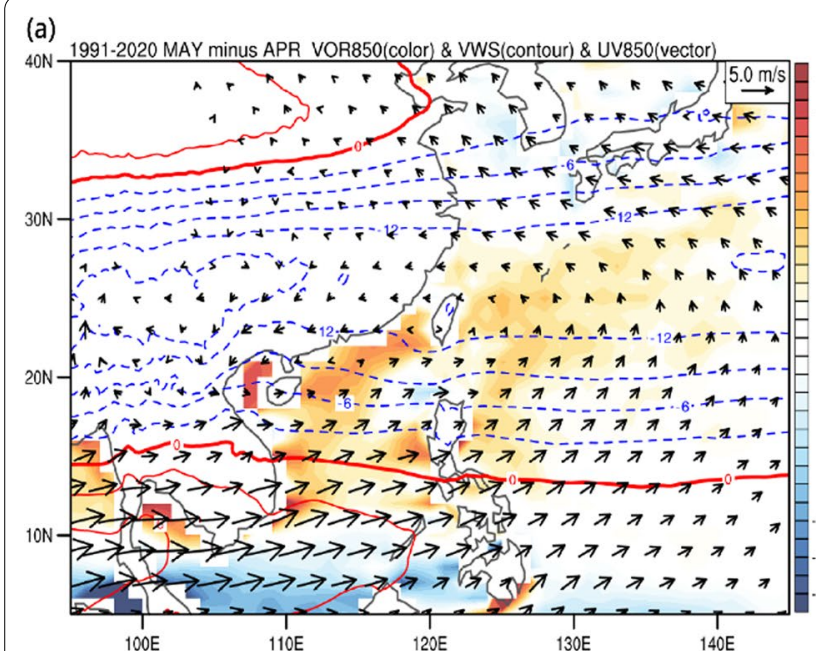

(b)

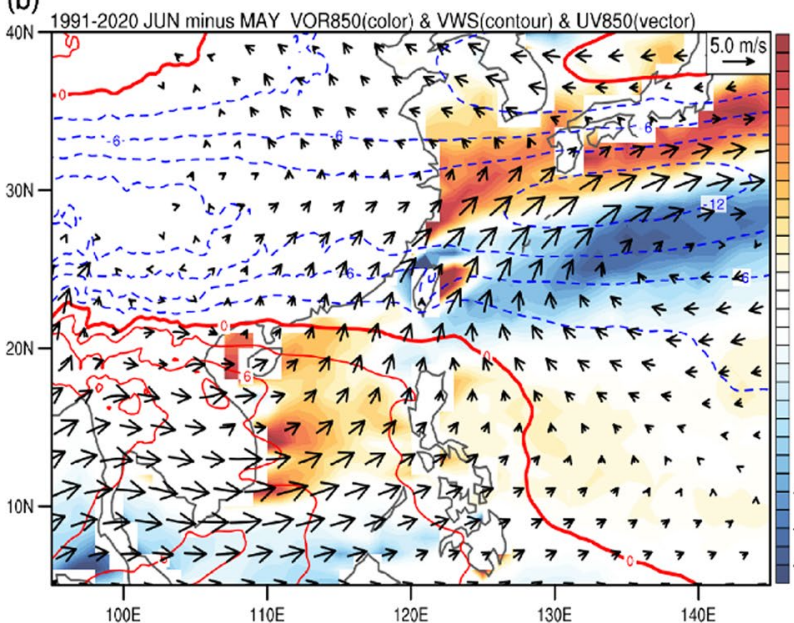

(c)

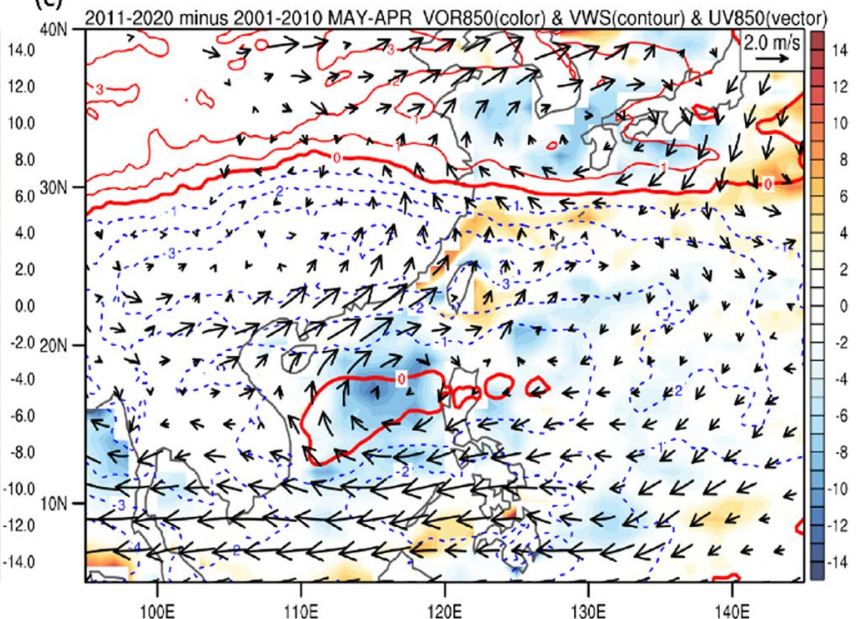

(d)

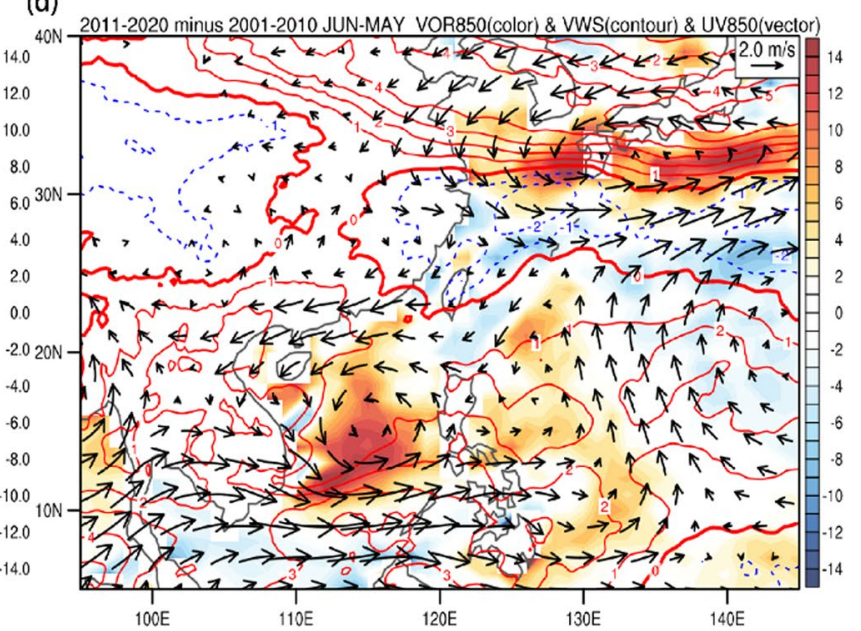

Fig. 7 The mean of $850 \mathrm{hPa}$ relative vorticity (shading, $10^{-5} \mathrm{~s}^{-1}$ ), vertical wind shear (contours, $\mathrm{ms}^{-1}$ ) and $850 \mathrm{hPa}$ winds (vectors, $\mathrm{ms}^{-1}$ ) for $1991-$ 2020 in a May minus April and $\mathbf{b}$ June minus May. The contour interval is $3 \mathrm{~ms}^{-1}$. The red solid (blue dashed) contours denoted positive (negative) values. As in a-b, c-d for 2011-2020 minus 2001-2010. The contour interval is $1 \mathrm{~ms}^{-1}$

during the later halves of April, May and June. The rainfall during April-June over $0^{\circ}$ to $5^{\circ} \mathrm{S}$ in general is above normal. Away from the equatorial belt over $10^{\circ} \mathrm{N}$ to $20^{\circ} \mathrm{N}$ at the SCS (Fig. 9g) see pronounced dry anomaly during May and wet anomaly during early June and dry during late June. However, the opposite anomalous pattern appears over the WNP (Fig. 9h) where the rainfall anomaly is above normal during May and below normal during June over $10^{\circ} \mathrm{N}$ to $20^{\circ} \mathrm{N}$.

In summary, we found that the advanced monsoon onset condition documented in the earlier literatures is unique to the decade of 2001-2010. After 2011, we did not observe the advanced monsoon onset during the past decade. Instead, we found the SCSSM onset was delayed and the TC activity was extremely inactive in May.

\subsection{Tropical deep convection and circulation}

In this section, we will discuss the large-scale patterns of the decadal changes in tropical deep convection and circulation that are related to the TC activity in May. We first checked the convection and circulation anomalies during April and May averaged over the decades before and after 2011 (Figs. 10 and 11). The enhanced low-level cross-equatorial over the western Indian Ocean is clearly shown in Fig. 10b. The anomalous monsoonal westerly flow extended from the western Indian Ocean and southern ArS through the southern tip of India peninsula, the $\mathrm{BOB}$, the Indochina peninsular, the SCS to the Philippine Sea and western Pacific. A cyclonic wind pattern over the SCS and the Philippine Sea that resembles the monsoon trough can be clearly identified in Fig. 10b which is collocated with the active convection represented by the negative OLR in Fig. 10d. It is interesting to note that the 


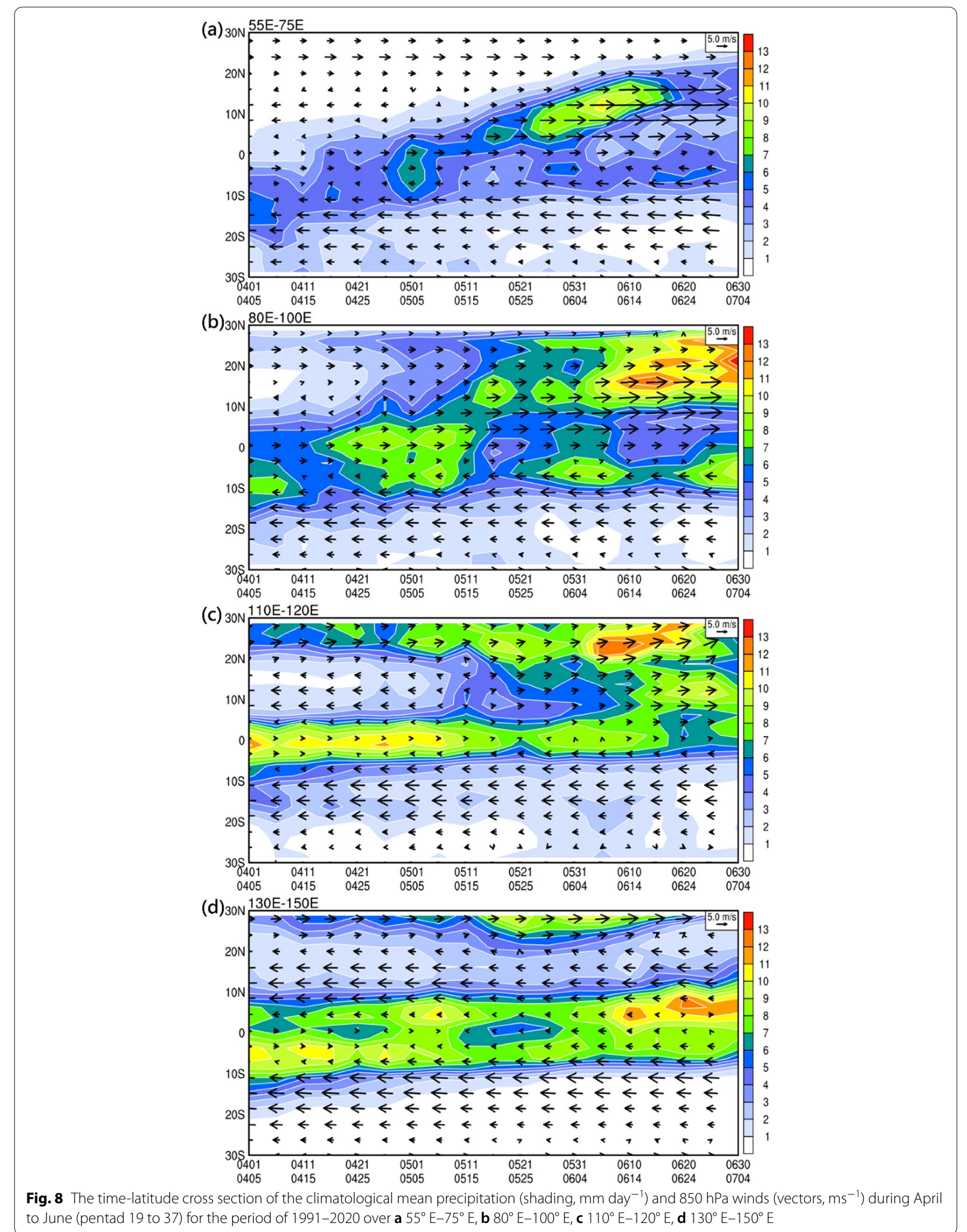



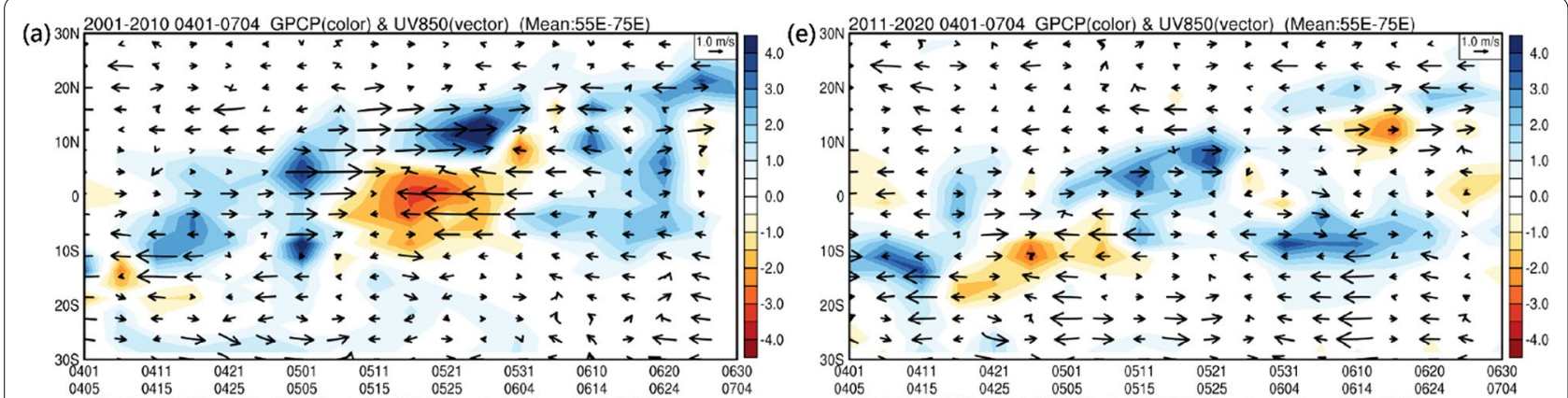

(b) 300 2001-2010 0401-0704 GPCP(color) \& UV850(vector) (Mean:80E-100E)
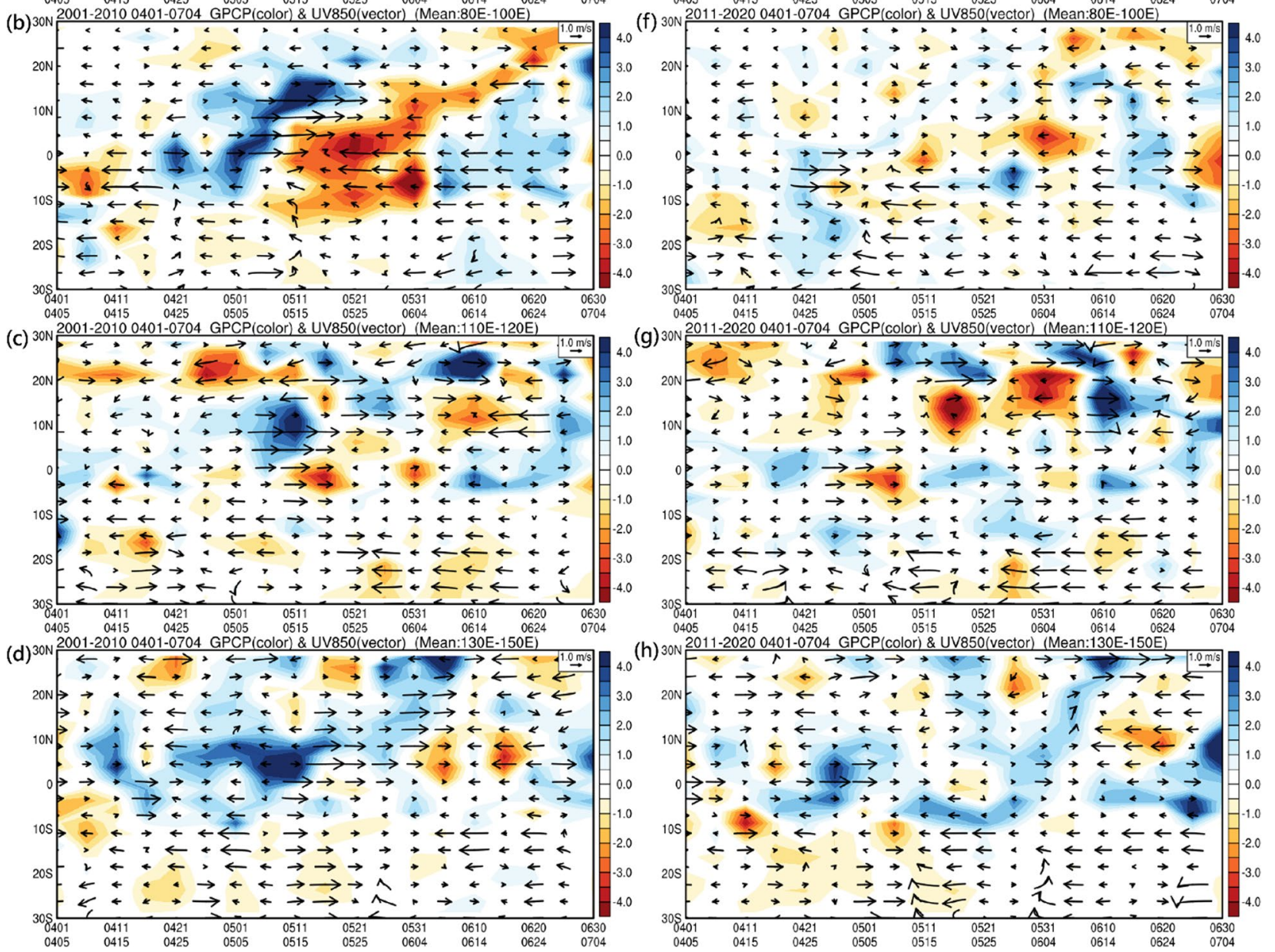

Fig. 9 Comparisons of precipitation (shading, $\mathrm{mm} \mathrm{day}^{-1}$ ) and 850-hPa winds (vectors, $\mathrm{ms}^{-1}$ ) anomalies between the $2001-2010$ (a-d) and 2011-2020 (e-h). The time-latitude cross section during April to June (pentad 19 to 37 ) relative to the mean for $1981-2000$ over $\mathbf{a}, \mathbf{e} 55^{\circ} \mathrm{E}-75^{\circ} \mathrm{E}, \mathbf{b}, \mathbf{f}$ $80^{\circ} \mathrm{E}-100^{\circ} \mathrm{E}, \mathbf{c}, \mathbf{g} 110^{\circ} \mathrm{E}-120^{\circ} \mathrm{E}, \mathbf{d}, \mathbf{h} 130^{\circ} \mathrm{E}-150^{\circ} \mathrm{E}$

east-west elongated enhanced convection is located near the enhanced easterly vertical wind shear with the lowerlevel westerly anomaly and upper-level easterly anomaly over the latitudes of $5^{\circ} \mathrm{N}-15^{\circ} \mathrm{N}$ from the western Indian Ocean to the western Pacific warm pool region. Figure 10c shows that the anomalous convection similar to May already appears in April over the western tropical Pacific $\left(10^{\circ} \mathrm{S}-10^{\circ} \mathrm{N}, 130^{\circ} \mathrm{E}-160^{\circ} \mathrm{E}\right)$ and the southern part of BOB and SCS. In Fig. 10a over the Philippine Sea $\left(0^{\circ}-15^{\circ} \mathrm{N}, 125^{\circ} \mathrm{E}-140^{\circ} \mathrm{E}\right)$ is an anomalous cyclonic circulation and over the north of New Guinea and the Pacific islands in the Southern Hemisphere is the convergence of anomalous equatorial westerly and easterly winds. Therefore, the east-west elongated enhanced convection (Fig. 10d) and associated anomalous easterly vertical wind shear (Fig. 10b, d) was likely triggered and sustained 


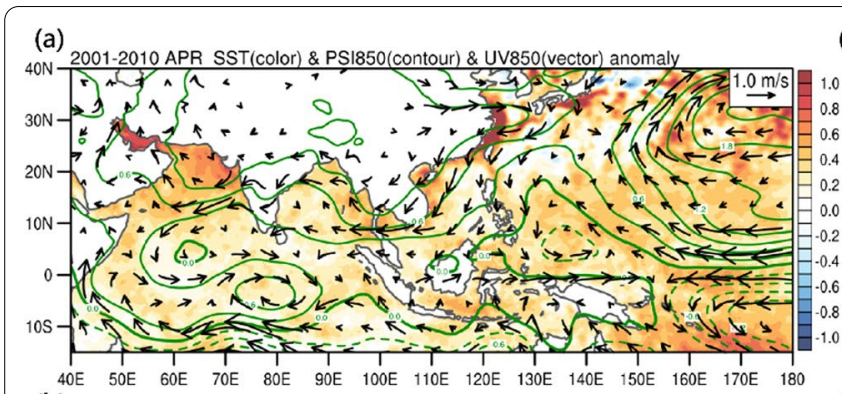

(b)

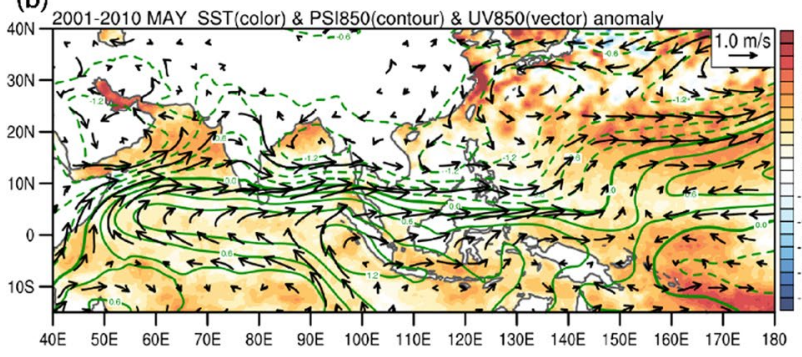

(c)

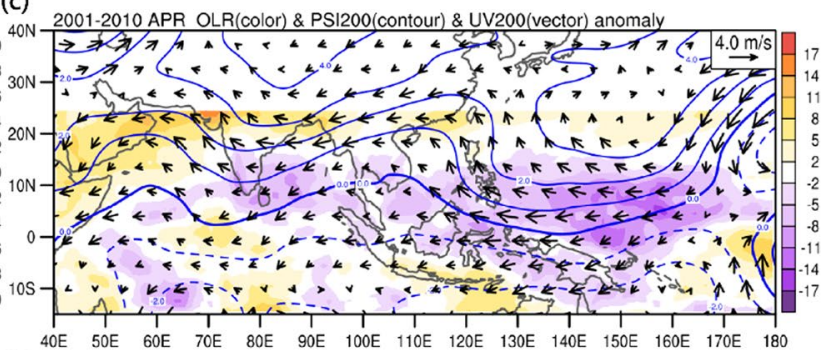

(d)

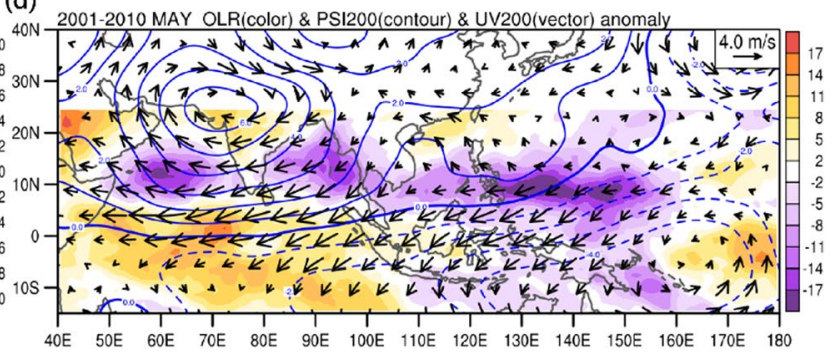

Fig. 10 The SST (shading, ${ }^{\circ} \mathrm{C}$ ), $850 \mathrm{hPa}$ stream function (contours, $\mathrm{m}^{2} \mathrm{~s}^{-1} 10^{6}$ ) and $850 \mathrm{hPa}$ winds (vectors, $\mathrm{ms}^{-1}$ ) anomalies for $2001-2010$ relative to the mean for 1981-2000 in a April and $\mathbf{b}$ May. The contour interval is $0.3 \mathrm{~m}^{2} \mathrm{~s}^{-1} 10^{6}$. As in $\mathbf{a}-\mathbf{b}$, but for outgoing long-wave radiation (shading, $\mathrm{Wm}^{-2}$ ), $200 \mathrm{hPa}$ stream function (contours, $\mathrm{m}^{2} \mathrm{~s}^{-1} 10^{6}$ ) and $200 \mathrm{hPa}$ winds (vectors, $\mathrm{ms}^{-1}$ ) in c April and $\mathbf{d}$ May. The contour interval is $1 \mathrm{~m}^{2} \mathrm{~s}^{-1} 10^{6}$

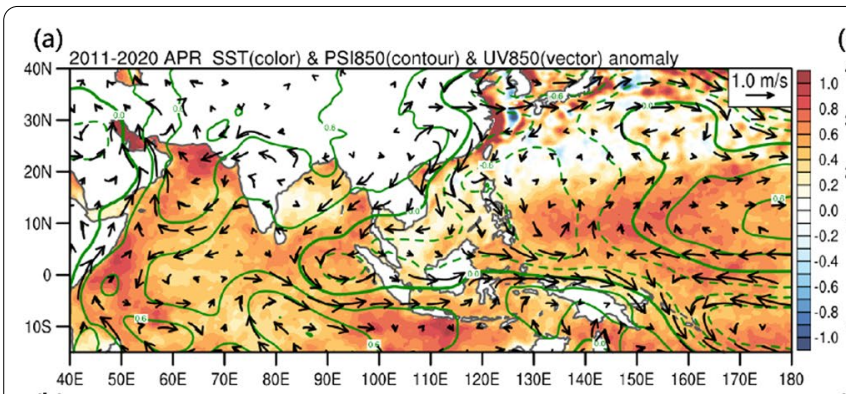

(b)

(c)
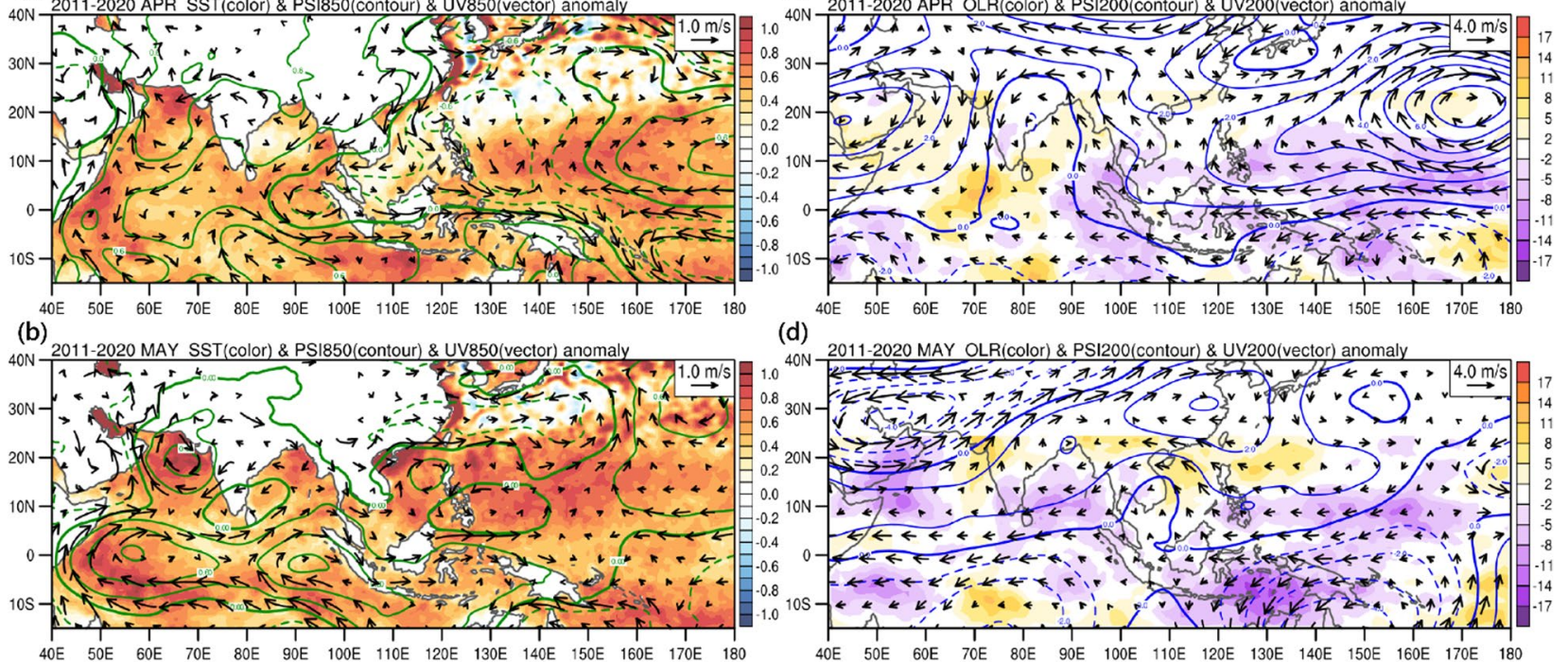

(d)

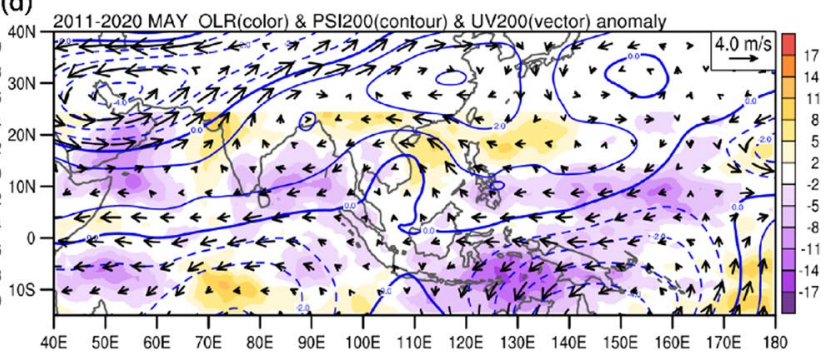

Fig. 11 The a-d panels are the same as Fig. 10a-d, but for the period of 2011-2020 relative to the mean for 1981-2000

by the active convection over the western Pacific and the Indian Ocean and Pacific SST gradient associated with the spring season La Nina condition (Xiang and Wang 2013).

Figure 11 shows that during the decade after 2011 the western Pacific became warmer than the previous decade and the warm anomalies expanded more northward to the subtropical Indo-Pacific region. The convergence of anomalous equatorial westerly and easterly winds to the north of New Guinea can be clearly identified in Fig. 11a, but the aforementioned Philippine Sea anomalous cyclonic circulation in Fig. 10a is not confined to the Philippine Sea but expanded to a much larger scale of an anomalous cyclonic circulation over the WNP at $\left(0^{\circ}-25^{\circ}\right.$ $\left.\mathrm{N}, 125^{\circ} \mathrm{E}-145^{\circ} \mathrm{E}\right)$. An important difference between Figs. 10a and 11a over the Indian Ocean is worth to note. 
Figure 10a shows during April of 2001-2010 the anomalous low-level zonal component of the winds over the Indian Ocean is mainly symmetric to the equator such that the anomalous zonal winds have the same sign over $10^{\circ} \mathrm{N}$ and $10^{\circ} \mathrm{S}$ and anomalous equatorial westerly winds over the western Indian Ocean. The equatorial westerly anomaly is associated with the relatively dry condition represented by the positive OLR anomaly in Fig. 10c. Figure 11a shows that during April of 2011-2020 over the Indian Ocean the anomalous low-level zonal component of the winds is mainly antisymmetric with respect to the equator such as the anomalous zonal winds have the opposite sign over $10^{\circ} \mathrm{N}$ and $10^{\circ} \mathrm{S}$ and anomalous cross equatorial flow can be identified near the western boundary of the Indian Ocean and near $90^{\circ} \mathrm{E}$. Over the eastern equatorial Indian Ocean in Fig. 11a we see counterclockwise circulation that also covers the northern part of Sumatra island. One of the big differences between Figs. 10c and $11 \mathrm{c}$ is the convection over the $\mathrm{BOB}$ and southern part of the SCS, where the mean April convection is above normal during 2001-2010 (Fig. 10c) while below normal during 2011-2020 (Fig. 11c). Although the mean convection over $\mathrm{BOB}$ and $\mathrm{ArS}$ in May are above normal (Fig. 11d), it is below normal over the SCS. Associated with the SCS below normal convection, Fig. 11b shows a low-level anticyclonic circulation that covers the northern part of SCS and the Philippine Sea. This feature is consistent with the weaker convection represented by the positive OLR anomaly (Fig. 11d). The more convective region in Fig. 11d such as that over the Indonesia maritime continent and the Arafura Sea, consistent anomalies can also be identified in Fig. $9 \mathrm{~h}$.

In order to enhance the decadal-scale contrast between the decades before and after 2011, we plotted the 850$\mathrm{hPa}$ wind and SST difference in Fig. 12a and the 200-hPa wind and OLR difference in Fig. 12b. Only the differences statistically significant at the 0.1 level are shown in the figures. The zonally elongated positive OLR difference to the north of $10^{\circ} \mathrm{N}$ in Fig. $12 \mathrm{~b}$ is striking. It covers the region from the ArS, BOB, the Indochina peninsula, the SCS, the Philippine Sea, and further to the western Pacific and the Coral Sea in the Southern Hemisphere. To the south of the large positive OLR difference region, which shows a decadal-scale suppressed tendency of the tropical deep convection, is the negative OLR difference that covers the entire equatorial Indian Ocean, the Indonesia maritime continent and the Arafura Sea. Associated with the active convection over the eastern Indian Ocean to the south of Sumatra island we see a large area of southerly winds blowing in the direction from the eastern South Indian Ocean $\left(80^{\circ} \mathrm{E}-110^{\circ} \mathrm{E}, 10^{\circ}\right.$ $\mathrm{S}-15^{\circ} \mathrm{S}$ ) cross the equator to the Northern Hemisphere. Figure 12a shows that at $850 \mathrm{hPa}$ is a cyclonic (counterclockwise) circulation in association with the east-west elongated negative OLR belt from the western equatorial Indian Ocean extending southeastward to the Arafura Sea (Fig. 12b). To the north of the cyclonic circulation is strong easterlies extending from the WNP through the SCS to the northern Indian Ocean. The strong easterlies suggest the decadal-scale weakening of the monsoonal westerly flow. Note that the low-level cyclonic winds over the western South Indian Ocean $\left(40^{\circ} \mathrm{E}-90^{\circ} \mathrm{E}, 0^{\circ}-10^{\circ} \mathrm{S}\right)$ (Fig. 12a) is associated with the enhanced convection represented by the negative OLR in Fig. 11d that resembles the ITCZ. The relationship between the enhanced ITCZ and monsoon evolution can be found in Fig. 9a and e where we see wetter signals over the latitudes of $0^{\circ}-10^{\circ}$ S during 2011-2020 (Fig. 9e) compared with the precipitation during 2001-2010 (Fig. 9a).

The decadal-scale contrast patterns have an important implication for Taiwan Mei-yu. The enhanced anticyclone over the SCS and the Philippine Sea and the weakened cyclonic circulation over the $\mathrm{BOB}$ all together can weaken the moisture supply from the tropics and result
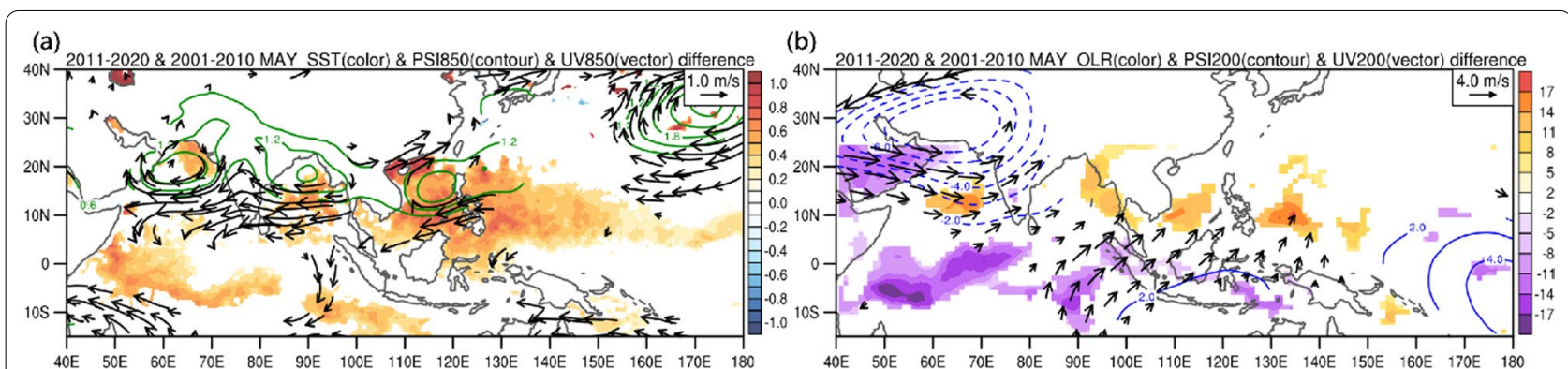

Fig. 12 a The difference of SST (shading, ${ }^{\circ} \mathrm{C}$ ), $850 \mathrm{hPa}$ stream function (contours, $\mathrm{m}^{2} \mathrm{~s}^{-1} 10^{6}$ ) and $850 \mathrm{hPa}$ winds (vectors, $\mathrm{ms}^{-1}$ ) for the period of 2011-2020 minus 2001-2010 in May. The contour interval is $0.3 \mathrm{~m}^{2} \mathrm{~s}^{-1} 10^{6}$. b As in $\mathbf{a}$, the difference of outgoing long-wave radiation (shading, $\mathrm{Wm}^{-2}$ ), $200 \mathrm{hPa}$ stream function (contours, $\mathrm{m}^{2} \mathrm{~s}^{-1} 10^{6}$ ) and $200 \mathrm{hPa}$ winds (vectors, $\mathrm{ms}^{-1}$ ). The contour interval is $1 \mathrm{~m}^{2} \mathrm{~s}^{-1} 10^{6}$. The significant at the $90 \%$ confidence level are shown 
in less rainfall in Taiwan. However, the cyclonic circulation over south China can increase the influence of midlatitude disturbances. When the southwesterly flow over the northern tip of the SCS is intensified, it can increase the probability of extreme rainfall events in Taiwan (Cho and $\mathrm{Lu}$ 2017).

\section{Discussion}

After seeing the decadal changes of the timing of the SCS summer monsoon onset and its relationship with the TC activity, the focus in this section is on discussing the possible SST influence on the decadal changes. The SCSSM onset process is characterized by the reversal of low-level zonal wind from easterlies to westerlies and a seasonal transition from the dry to wet regime over the central SCS from $5^{\circ} \mathrm{N}$ to $15^{\circ} \mathrm{N}$ and $110^{\circ} \mathrm{E}$ to $120^{\circ} \mathrm{E}$, which is usually associated with a retreat of the westward extension of the WPSH from the SCS to the Philippine Sea. The normal onset time identified using the $850-\mathrm{hPa}$ zonal wind (U850) averaged over the month of May in the area of $110^{\circ} \mathrm{E}-120^{\circ} \mathrm{E}$ and $5^{\circ} \mathrm{N}-15^{\circ} \mathrm{N}$ is in pentad $28(16-20$ May) (Lu et al. 2020). When the monthly mean $850-\mathrm{hPa}$ zonal wind over the index region during May is weaker than normal the onset is usually relatively late. Figure 13 shows that the May monthly mean U850 anomaly over the SCS is stronger during the decade of 2001-2010 than the decade of 2011-2020. A transition from negative anomaly to positive appears in $1993 / 1994$ as previously

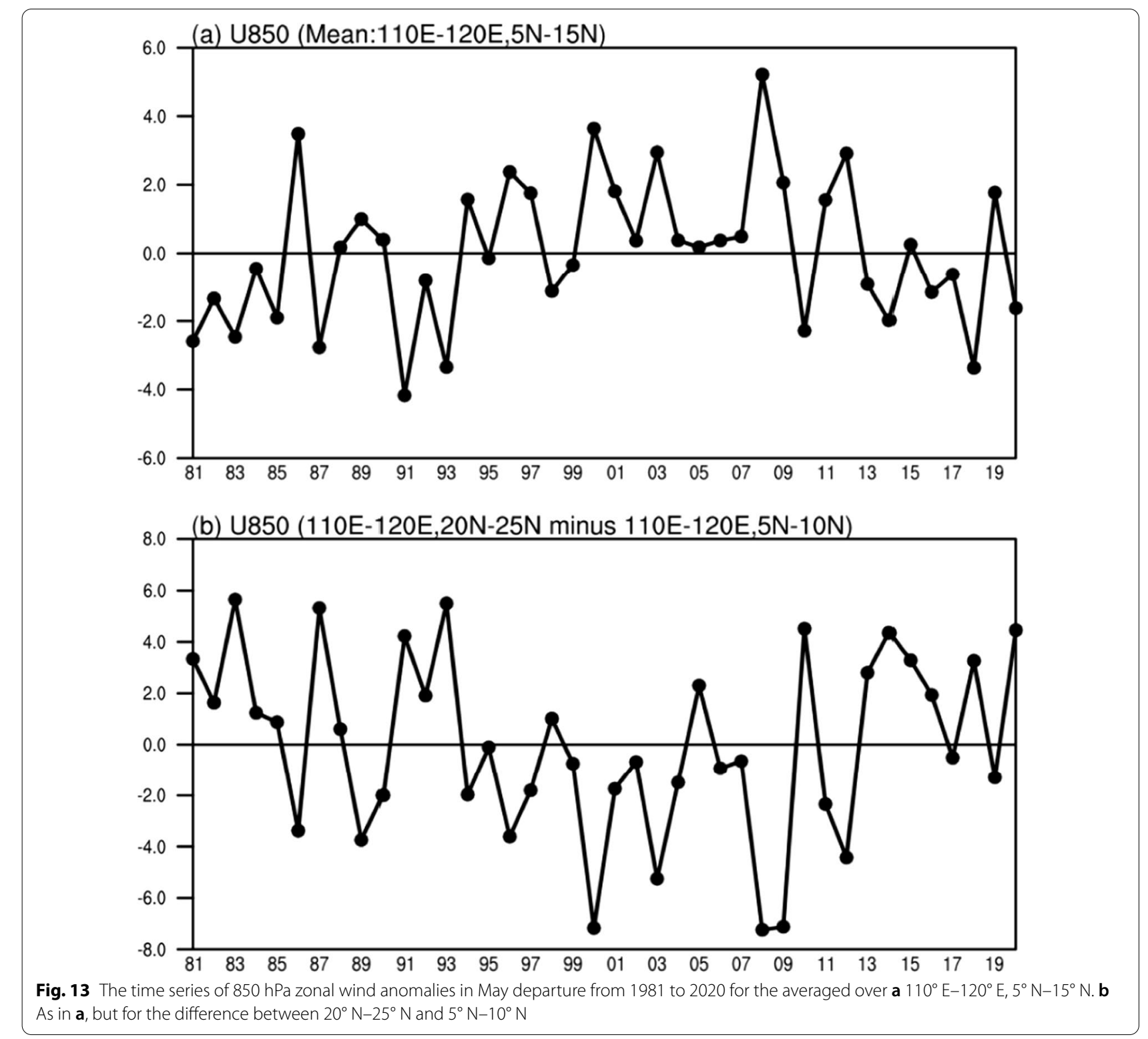


mentioned by many authors (for example, Kajikawa and Wang 2012; Liu et al. 2016). The meridional wind shear calculated as the difference between two latitudinal bands of $20^{\circ} \mathrm{N}-25^{\circ} \mathrm{N}$ and $5^{\circ} \mathrm{N}-10^{\circ} \mathrm{N}$ (the former minus the latter) of U850 averaged over the longitudes of $110^{\circ} \mathrm{E}-120^{\circ}$ $E$ is presented in Fig. 13b. Positive wind shear represents negative vorticity or anticyclonic circulation. It is clearly shown that when the SCS westerly is weak, the circulation anomaly tends to be in the anticyclonic direction. The strong anticyclonic anomaly during the decade of 2011-2020 is consistent with the wind fields presented in Figs. 10, 11, and 12.

The decadal-scale contrast of the SCSSM onset time is mainly influenced by the Indo-Pacific SST patterns, especially ENSO. The time series of the springtime (April-May) SST averaged over the Niño $3\left(5^{\circ} \mathrm{S}-5^{\circ} \mathrm{N}\right.$, $\left.150^{\circ} \mathrm{W}-90^{\circ} \mathrm{W}\right)$, Niño $4\left(5^{\circ} \mathrm{S}-5^{\circ} \mathrm{N}, 160^{\circ} \mathrm{E}-150^{\circ} \mathrm{W}\right)$, the SCS $\left(0^{\circ}-10^{\circ} \mathrm{N}, 110^{\circ} \mathrm{E}-120^{\circ} \mathrm{E}\right)$ and the western equatorial Pacific (WEP) $\left(5^{\circ} \mathrm{S}-5^{\circ} \mathrm{N}, 130^{\circ}-150^{\circ} \mathrm{E}\right)$ are presented in Fig. 14. First, we notice that the variation characteristics are different in four regions. The grand La Niña period can be clearly identified in Niño 3 (Fig. 14a) where the time series show persistent small negative anomalies from the year 1999 to 2013. Niño 4 (Fig. 14b) shows that the warmest anomaly over the 40 years (1981-2020) period occurred in 2015 and 2016. The coldest three springs occurred in 1999, 2000 and 2008 (Fig. 14b) which are all in the grand La Niña period. Niño 4 shows larger interannual variability than Niño 3 . Figure $14 \mathrm{c}$ shows that the SCS SST variability is unusually large during the tenyear period from 2008 to 2017 . Different from the characteristics of the other four regional mean SST indices, the WEP shows a sharp contrast of a negative anomaly regime before 1999 and a positive regime after 1999.

The Indo-Pacific SST gradient has more profound influence on the low-level wind patterns over the SCS. Figure 15 shows the time-latitude cross sections of the SST anomalies averaged over the Indian Ocean $\left(80^{\circ}\right.$ $\left.\mathrm{E}-110^{\circ} \mathrm{E}\right)$ and the western Pacific $\left(140^{\circ} \mathrm{E}-170^{\circ} \mathrm{E}\right)$, and the difference between these two longitudinal bands. Figure 15a shows that over the Indian Ocean the SST was relatively cold before 1999 but relatively warm after 2013 . During the period from 1999 to 2013, the SST fluctuated with the period of roughly 2-3 years. The persistent warm condition after 2013 has never occurred before in 40 years. Figure 15b presents an entirely different variation pattern over the western Pacific. It shows that in the lower latitudes to the south of $15^{\circ} \mathrm{N}$ the SST before 1999 is colder than the SST after 1999. In the latitudes to the north of $15^{\circ} \mathrm{N}$, although the SST before 1999 is colder than the SST after 1999, the interannual fluctuation is stronger than the lower latitudes. Figure $15 \mathrm{c}$ shows the difference between the SST over the Indian Ocean and the western Pacific, where the positive difference means the Indian Ocean SST is abnormally warmer than the Pacific SST. The figure suggests that on average during the period before 1999 the Indian Ocean is warmer than the Pacific, while after 1999 the Pacific Ocean SST is warmer than the Indian Ocean. During the recent years after 2013, we notice that in the lower latitudes there is large interannual fluctuation in the difference, while to the north of $15^{\circ} \mathrm{N}$ the Indian Ocean is persistently warmer than the Pacific. The persistency is mainly due to the warm condition over the Indian Ocean. The SST contrast is not favorable for the warm and moist westerly monsoonal flow to penetrate through the Indochina Peninsula to the SCS.

The inter-decadal difference of the wind, vorticity at $850 \mathrm{hPa}$ and the precipitation during April and May are presented in Fig. 16a. The weaker low-level vorticity and the enhanced anticyclonic circulation associated with the enhanced easterly winds are evident. The lower-latitude easterly anomalies can be resulted from the warmer SST over the Indian Ocean. However, the enhanced westerlies to the north of $20^{\circ} \mathrm{N}$ is likely to be associated with the enhanced cyclonic circulation over the eastern Asian continent. The enhanced cyclonic circulation is supported by Fig. 16b which shows that over the land area of East Asia the $2 \mathrm{~m}$ air temperature during the later decade was much warmer than the earlier decade. We also checked the decadal difference in the precipitable water (figure not shown) and found that over northern China $\left(105^{\circ} \mathrm{E}-120^{\circ} \mathrm{E}, 30^{\circ} \mathrm{N}-40^{\circ} \mathrm{N}\right)$ the water vapor during the later decade was more abundant than the earlier decade. Therefore, the intensified westerly winds over the northern tip region of the SCS and the East China Sea is likely sustained by the cyclonic flow over land that associated with the warming tendency on the decadal time scale. The extremely weak vorticity over the SCS resulted from the westward tropical SST gradient and the enhanced cyclonic circulation over East Asia explains why the past decade of 2011-2020 is a period with the weakest preseason TC activity over the SCS.

\section{Summary and conclusions}

In this study, we analyzed the decadal scale changes of the Asian-Pacific monsoon transition patterns and the seasonal northward progression of monsoonal rain bands. The interdecadal variation influence on the WNP TC activity during May and June, in particular the TC activity over the SCS in May has been discussed. We found that over the SCS after the increase of the TC activity in May during the decade of 2001-2010, during the following decade (2011-2020) the TC activity sharply decreased. The TC genesis frequency in May dropped to the decadal minimum since 1961. The advanced Asian 
(a)

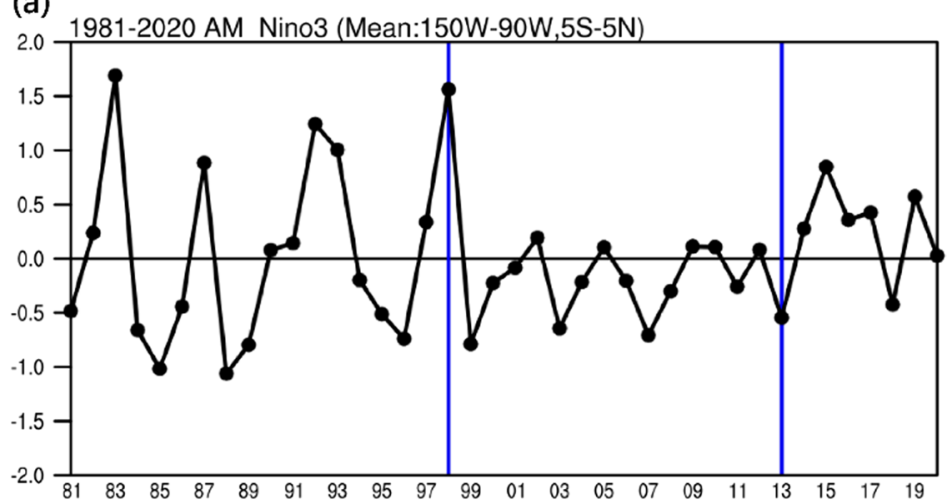

(b)

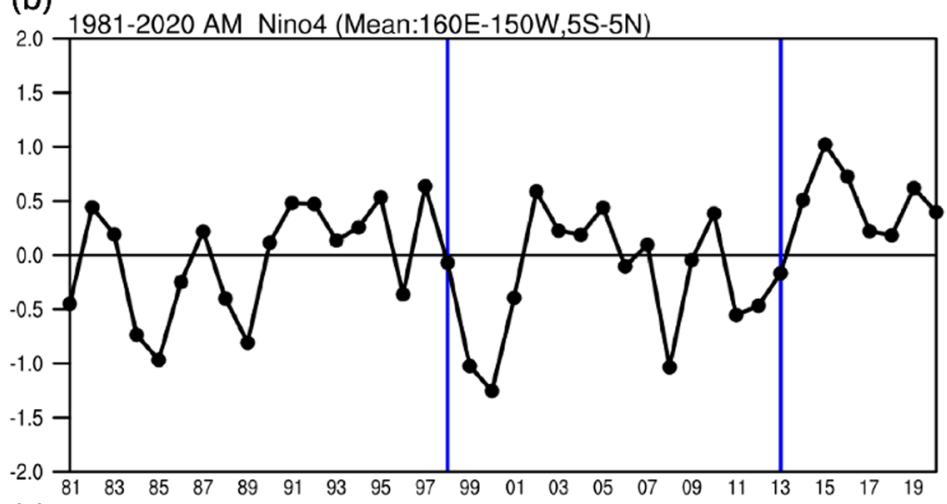

(c)

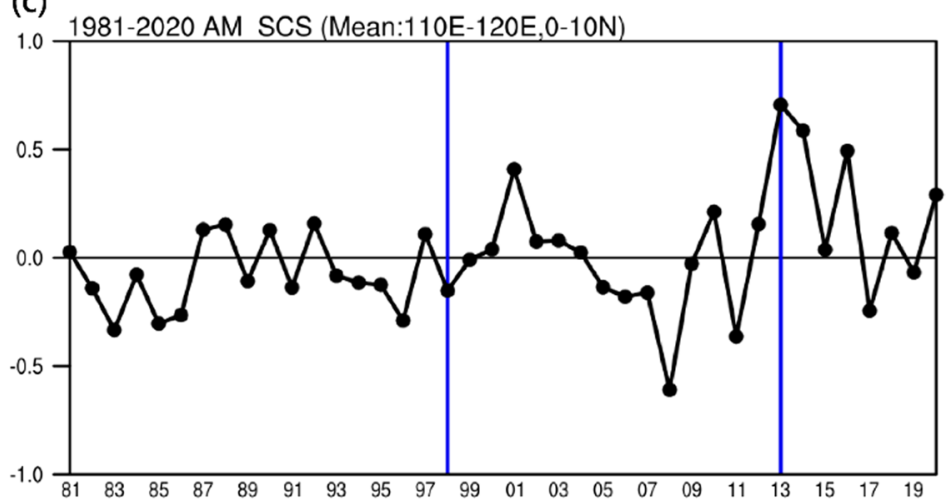

(d)

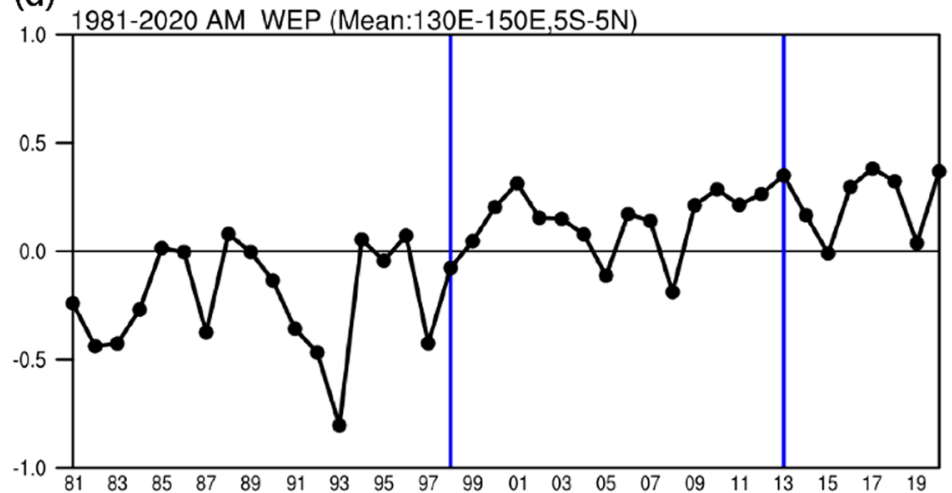

Fig. 14 Time series of area mean SST anomalies in AM (April-May) during the period of 1981-2020 over four regions. a Nino3 $\left(150^{\circ} \mathrm{W}-90^{\circ} \mathrm{W}, 5^{\circ}\right.$ $\left.\mathrm{S}-5^{\circ} \mathrm{N}\right)$, b Nino4 $\left(160^{\circ} \mathrm{E}-150^{\circ} \mathrm{W}, 5^{\circ} \mathrm{S}-5^{\circ} \mathrm{N}\right), \mathbf{c}$ SCS $\left(110^{\circ} \mathrm{E}-120^{\circ} \mathrm{E}, 0-10^{\circ} \mathrm{N}\right)$, and $\mathbf{d}$ WEP $\left(130^{\circ} \mathrm{E}-150^{\circ} \mathrm{E}, 5^{\circ} \mathrm{S}-5^{\circ} \mathrm{N}\right)$. The blue lines denoted the year of 1998 and 2013 
(a) 1981-2020 AM SST (Mean:80E-110E)

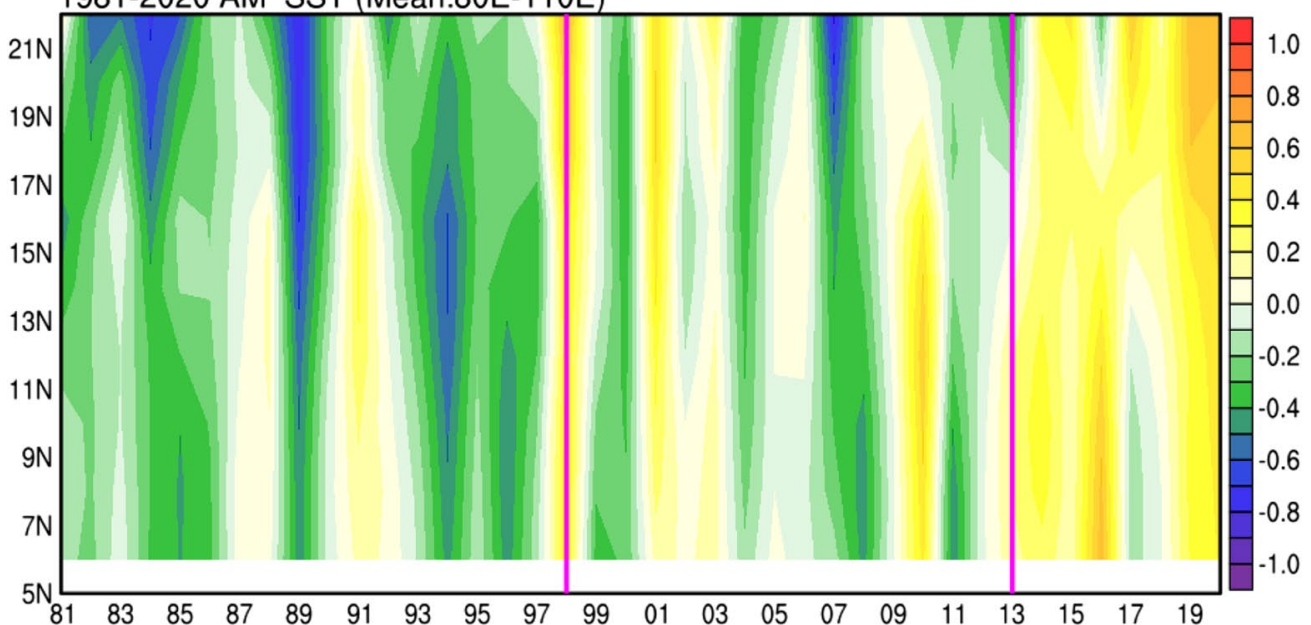

(b)

1981-2020 AM SST (Mean:140E-170E)

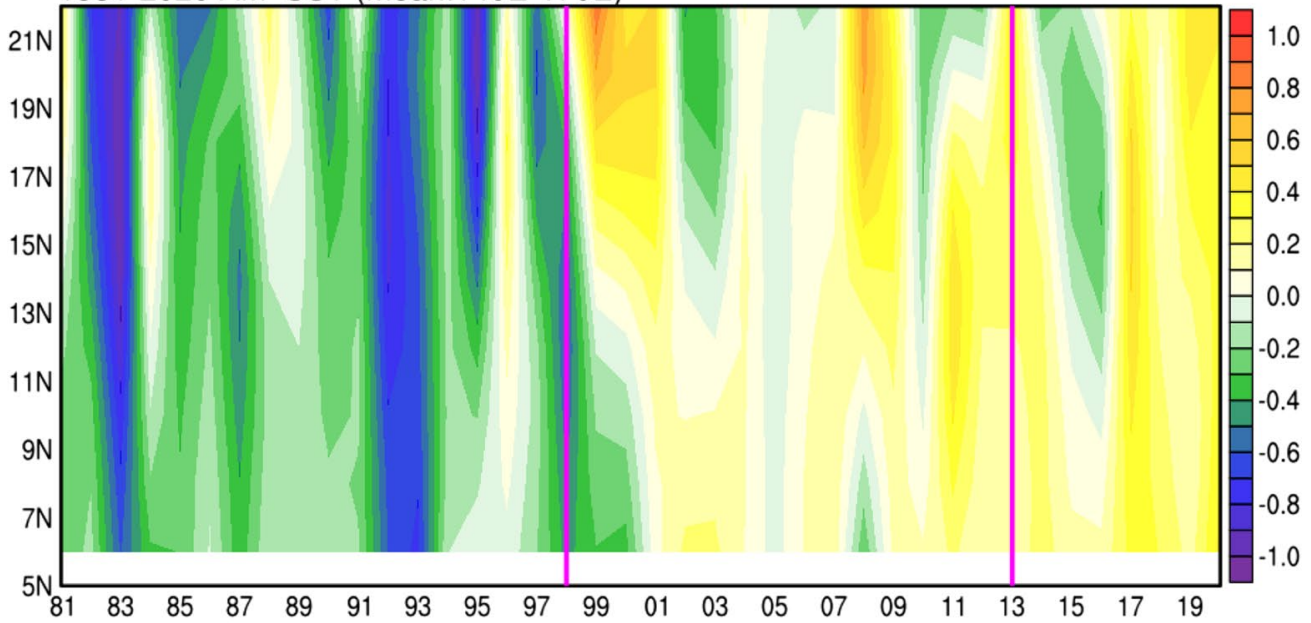

(c)

1981-2020 AM SST (80E-110E minus 140E-170E)

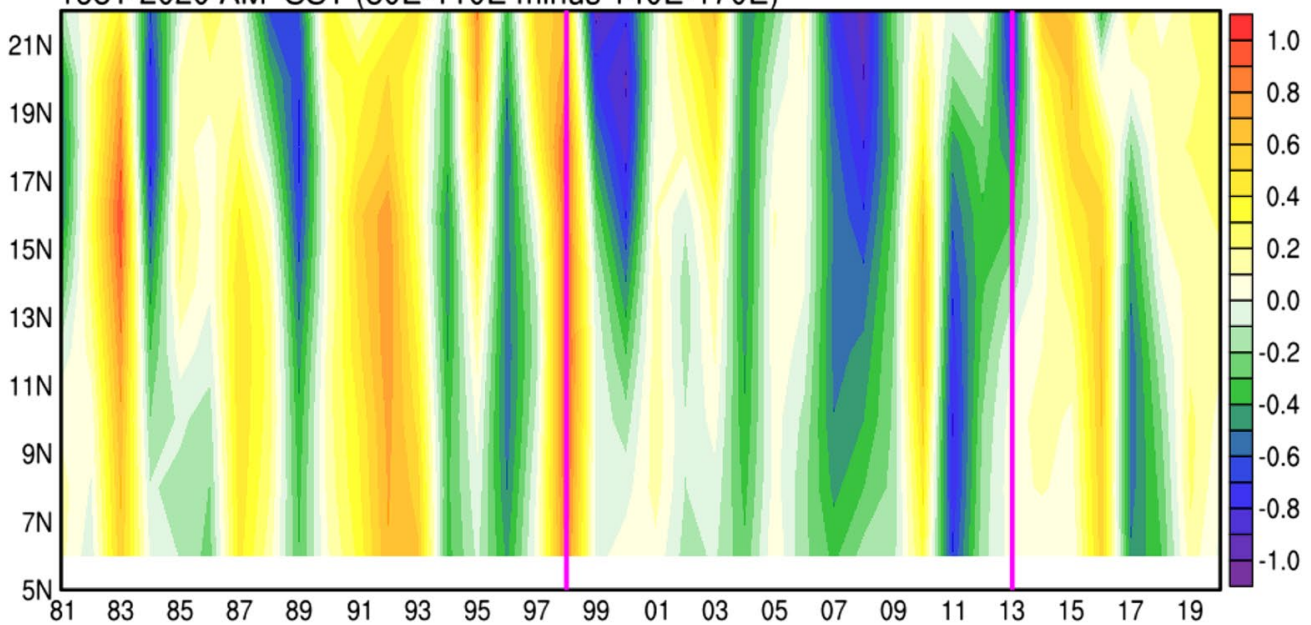

Fig. 15 The latitude-time diagram of SST anomalies in AM (April-May) for the period of $1981-2020$ over $\mathbf{a} 80^{\circ} \mathrm{E}-110^{\circ} \mathrm{E}$, and $\mathbf{b} 140^{\circ} \mathrm{E}-170^{\circ} \mathrm{E}$. $\mathbf{c}$ is the difference [(a) minus (b)]. The pink lines denoted the year of 1998 and 2013 
(a)

$40 \mathrm{~N}$ 2011-2020 minus 2001-2010 AM GPCP(color) \& VOR850(contour) \& UV850(vector)

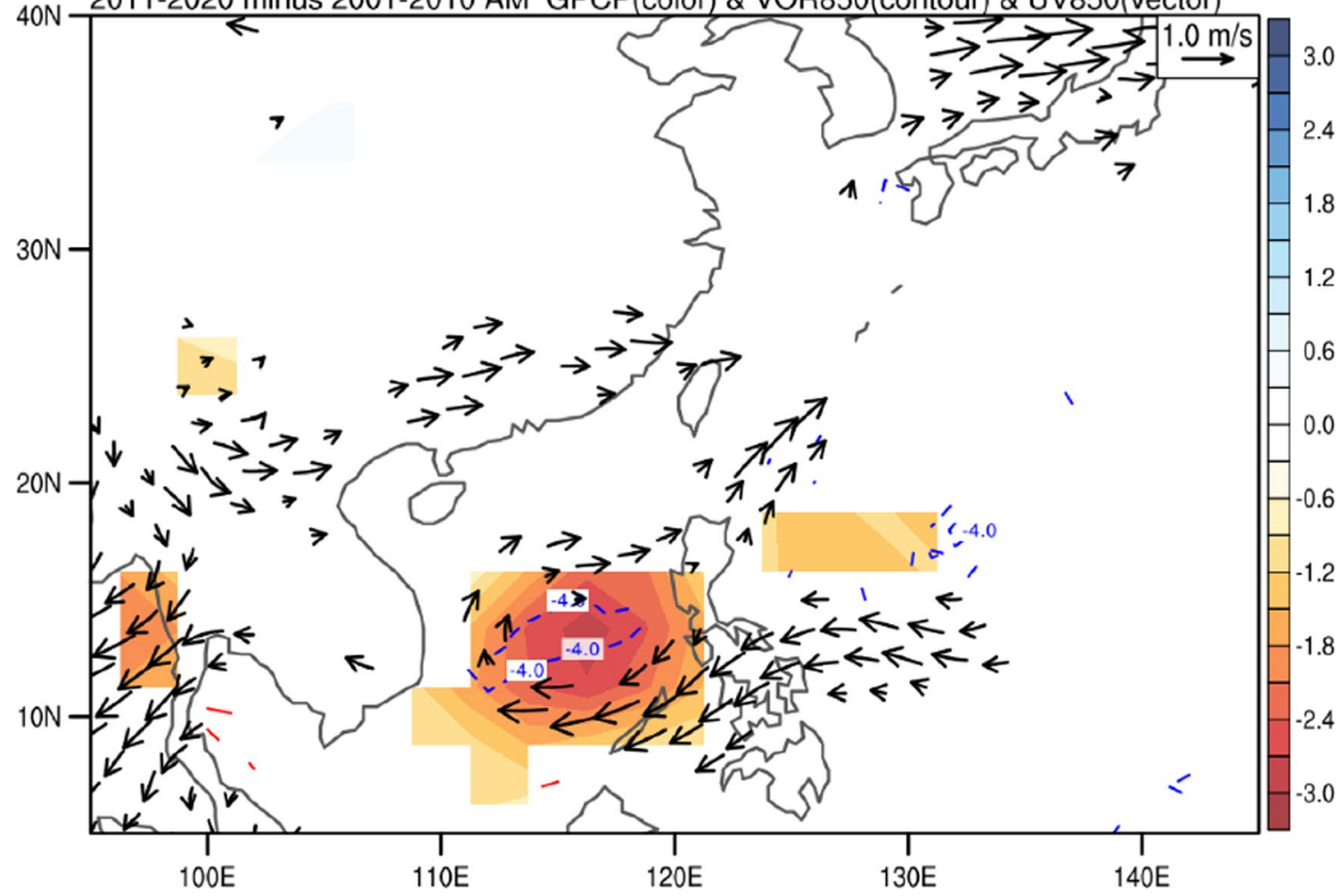

(b)

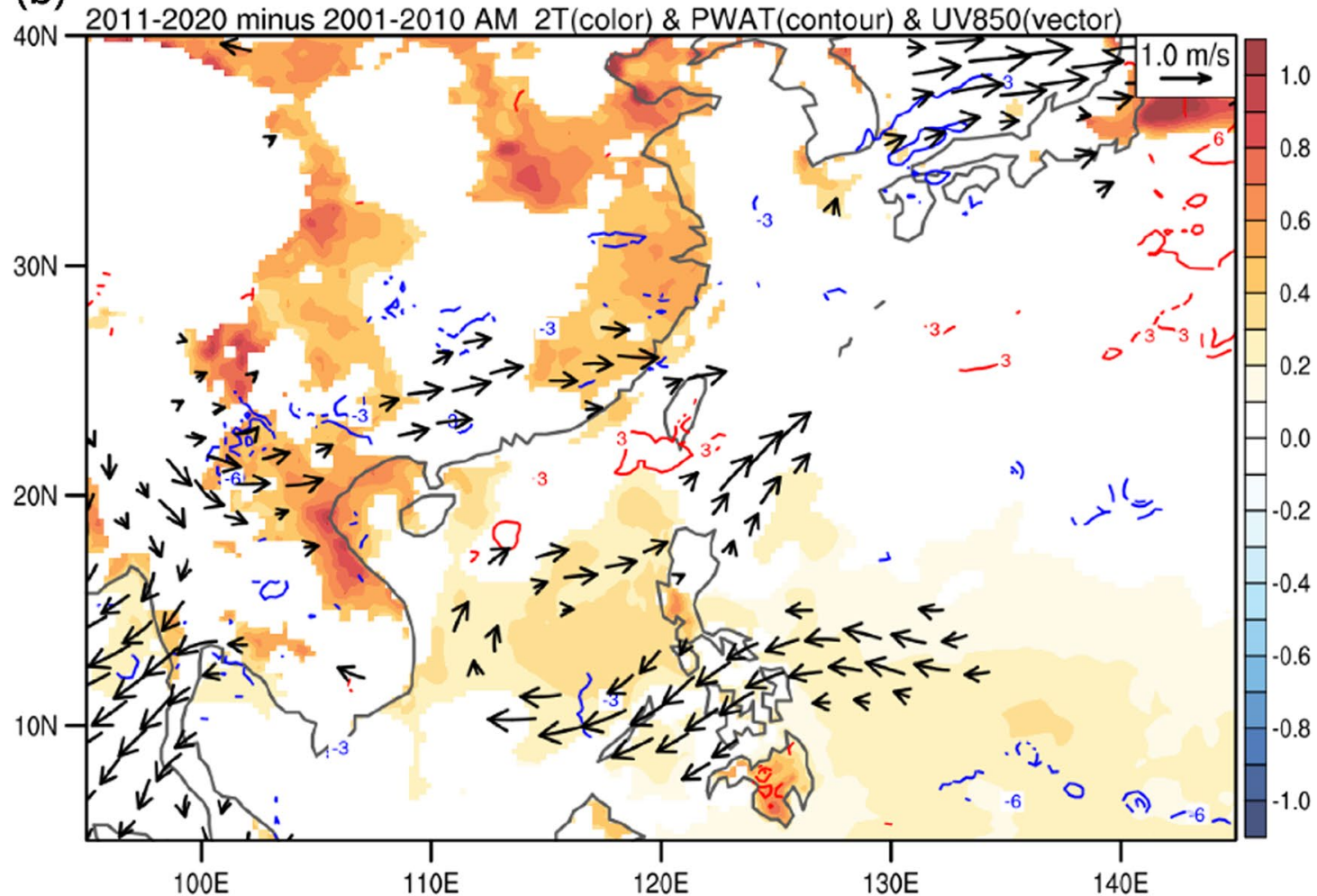

Fig. 16 The difference of large-scale environment in AM (April-May) for 2011-2020 minus 2001-2010. a Precipitation (shading, mm day ${ }^{-1}$ ), 850 hPa relative vorticity (contours, $\mathrm{s}^{-1} 10^{-5}$ ) and $850 \mathrm{hPa}$ winds (vectors, $\mathrm{ms}^{-1}$ ). The contour interval is $2 \mathrm{~s}^{-1} 10^{-5}$. b As in a, but the shading is $2 \mathrm{~m}$ air temperature $\left({ }^{\circ} \mathrm{C}\right)$ and the contours is total precipitable water $\left(\mathrm{kg} \mathrm{m}^{-2}\right)$. The significant at the $90 \%$ confidence level are shown 
monsoon onset during 2001-2010 was not observed during the decade after 2011 . The extremely weak TC activity over the SCS was associated with the strong anticyclonic circulation anomaly over the SCS. The enhanced anticyclone can be explained by the easterly anomalies to the south of $20^{\circ} \mathrm{N}$ which was sustained by the enhanced SST gradient by the abnormally warm SST over the Indian Ocean. To the north of $20^{\circ} \mathrm{N}$, the enhanced westerly anomalies was associated with the cyclonic circulation over the Asian continent. The abnormal low-level easterly anomalies reflected the warm and moist monsoonal westerly flow was weakened.

Many important questions this paper has not answered remained to future studies. For example, our study suggests that the monsoon transition from May to June during the past decade was sharper and stronger than before. It can result in more intense rainfall events over the Yangtze River and Japan in June and July that occurred in recent years (e.g. Blunden and Boyer 2021 and the references therein). More studies are needed to understand inter-decadal variations of the Asian-Pacific monsoon systems and its relationship with the variations of surface air temperatures over land and oceans.

\section{Acknowledgements}

This study is supported by the Ministry of Science and Technology, Taiwan, Grant Nos. MOST 109-2811-M-002-646-MY2, MOST109-2111-M-002-005, MOST 110-2111-M-002-013. CHS is supported by the Grant Nos. MOST 1092111-M-002-004, MOST 109-2119-M-001-011, MOST 110-2111-M-002-015, MOST 110-2119-M-002-012.

\section{Authors' contributions}

All the authors read and approved the final manuscript.

\section{Declarations}

\section{Competing interests}

The authors declare that they have no competing interests.

\section{Author details}

'Department of Atmospheric Sciences, National Taiwan University, Taipei, Taiwan (R.O.C.). ${ }^{2}$ Philippine Atmospheric Geophysical and Astronomical Services Administration, Quezon City, Philippines. ${ }^{3}$ Central Weather Bureau, Taipei, Taiwan.

Received: 27 January 2022 Accepted: 14 February 2022

Published online: 03 March 2022

\section{References}

Blunden J, Boyer T (2021) State of the climate in 2020. Bull Am Meteor Soc. https://doi.org/10.1175/2021BAMSStateoftheClimate.1

Cho Y-M, Lu M-M (2017) A downscaling method for predicting Taiwan Mei-yu seasonal extreme rainfall event frequency using a large-scale southwest flow index. Atmos Sci 45:83-100. https://doi.org/10.3966/025400022017064 502001 (in Chinese with English abstract)

Cho Y-M, Lu M-M (2021) Taiwan Mei-yu seasonal rainfall pattern and East Asian Summer Monsoon characteristics during the monsoon development stage. Atmos Sci 49:79-110. https://doi.org/10.3966/025400022021074901004 (in Chinese with English abstract)
Ding YH, Chan JC (2005) The East Asian summer monsoon: an overview. Meteor Atmos Phys 89:117-142. https://doi.org/10.1007/s00703-005-0125-z

Ding Y, Liang P, Liu YJ, Zhang YC (2020) Multiscale variability of Meiyu and its prediction: a new review. J Geophys Res 125(7):e2019JD031496. https://doi. org/10.1029/2019JD031496

Hersbach H, Bell B, Berrisford P, Hirahara S, Horányi A, Muñoz-Sabater J (2020) The ERA5 global reanalysis. Q J R Meteorol Soc 146:1999-2049. https://doi.org/ 10.1002/qj.3803

Huang B, Thorne PW, Banzon VF, Boyer T, Chepurin G, Lawrimore JH, Menne MJ, Smith TM, Vose RS, Zhang H-M (2017) Extended reconstructed sea surface temperature version 5 (ERSSTv5): upgrades, validations, and intercomparisons. J Clim 30(20):8179-8205. https://doi.org/10.1175/JCLI-D-16-0836.1

Huangfu J, Chen W, Jian M, Huang R (2019) Impact of the cross-tropopause wind shear on tropical cyclone genesis over the Western North Pacific in May. Clim Dyn 52(7):3845-3855. https://doi.org/10.1007/s00382-018-4363-4

Huffman GJ, Adler RF, Bolvin DT, Gu G (2009) Improving the global precipitation record: GPCP Version 21. Geophys Res Lett 36:L17808. https://doi.org/10. 1029/2009GL040000

Kajikawa Y, Wang B (2012) Interdecadal change of the South China Sea summer monsoon onset. J Clim 25(9):3207-3218. https://doi.org/10.1175/ JCLI-D-11-00207.1

Kajikawa Y, Yasunari T, Yoshida S, Fujinami H (2012) Advanced Asian summer monsoon onset in recent decades. Geophys Res Lett 39:L03803. https://doi. org/10.1029/2011GL050540

Lau KM (1992) East Asian summer monsoon rainfall variability and climate teleconnection. J Meteor Soc Jpn 70(1B):211-242. https://doi.org/10.2151/ jmsj1965.70.1B_211

Lau K-M, Kim K-M (2006) Observational relationships between aerosol and Asian monsoon rainfall, and circulation. Geophys Res Lett 33:L21810. https://doi. org/10.1029/2006GL027546

Lau KM, Kim MK, Kim KM (2006) Asian summer monsoon anomalies induced by aerosol direct forcing: the role of the Tibetan Plateau. Clim Dyn 26:855-864. https://doi.org/10.1007/s00382-006-0114-z

Lee H-T, NOAACDR Program (2011) NOAA climate data record (CDR) of daily outgoing longwave radiation (OLR), version 12. NOAA Natl Clim Data Center. https://doi.org/10.7289/N5SJ1HH2

Liu B, Zhu C, Yuan Y, Xu K (2016) Two types of interannual variability of South China Sea monsoon onset related to the SST anomalies before and after 1993/94. J Clim 29:6957-6958. https://doi.org/10.1175/JCLI-D-16-0065.1

Lu M-M, Sui C-H, Sun J-R, Lin P-H (2020) Influences of subseasonal to interannual oscillations on the SCS summer monsoon onset in 2018. Terr Atmos Ocean Sci 31(2):197-209. https://doi.org/10.3319/TAO.2020.02.25.01

Lyon B, Barnston AG, DeWitt DG (2014) Tropical Pacific forcing of a 1998-1999 climate shift: observational analysis and climate model results for the boreal spring season. Clim Dyn 43(3-4):893-909. https://doi.org/10.1007/ S00382-013-1891-9

Tu JY, Chou C, Huang P, Huang R (2011) An abrupt increase of intense typhoons over the western North Pacific in early summer. Environ Res Lett 6(3):034013. https://doi.org/10.1088/1748-9326/6/3/034013

Wang B, Ho L (2002) Rainy season of the Asian-Pacific summer monsoon. J Clim 15(4):386-398

Wang B, Wu R, Lau KM (2001) Interannual variability of the Asian summer monsoon: contrasts between the Indian and the western North Pacific-East Asian monsoons. J Clim 14(20):4073-4090. https://doi.org/10.1175/15200442(2001)014\%3c4073:IVOTAS\%3e2.0.CO;2

Xiang B, Wang B (2013) Mechanisms for the advanced Asian summer monsoon onset since the mid-to-late 1990s. J Clim 26(6):1993-2009. https://doi.org/ 10.1175/JCLI-D-12-00445.1

Xie P, Joyce R, Wu S, Yoo S, Yarosh Y, Sun F, Lin R (2017) Reprocessed, bias-corrected CMORPH global high-resolution precipitation estimates from 1998. J Hydrometeor 18:1617-1641. https://doi.org/10.1175/JHM-D-16-0168.1

Xu S, Wang B (2014) Enhanced western North Pacific tropical cyclone activity in May in recent years. Clim Dyn 42(9-10):2555-2563. https://doi.org/10.1007/ s00382-013-1921-7

\section{Publisher's Note}

Springer Nature remains neutral with regard to jurisdictional claims in published maps and institutional affiliations. 